\title{
Impact of Bio-Stimulates and some Different Nitrogen Sources on Maize and Wheat Productivity in Calcareous Soil
}

\author{
Sherif, A. E. A. ; K. S. El-Hedek and Sh. A. Abdelgwad
}

Soils, Water and Environ. Rese. Inst. (Agric. Res Center) Giza, Egypt.

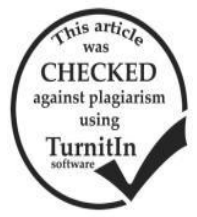

ABSTRACT

Maintaining soil fertility and the use of plant nutrients in sufficient and balanced amounts is one of the key factors for increasing crop yield and decreasing adverse environmental effects and pollutions arising from nonpoint fertilizer usage. Two field experiments were conducted during the summer and winter seasons at experiment at station of EL-Nubaria area El-Behira Governorate, Egypt. The aim of this study was to compare the effect of different rates and forms of nitrogen fertilizer, i.e., ammonium sulphate $(20.6 \% \mathrm{~N})$, ammonium nitrate $(33.5 \% \mathrm{~N}$ ), and Enciabien, $40 \% \mathrm{~N}$ (slow-release) with or without inoculation by (plant growth promoting rhizobactteria) (PGPR) on yield and nutrients concentrations of maize and wheat plants as well as soil fertility of calcareous soil and enzyme activity. Three sources of nitrogen fertilizer were applied as hand broadcast on the soil surface at three rates (50, 75 and $100 \%)$ from recommended doses of minerals nitrogen (60, 90 and 120) and (40,60 and 80) $\mathrm{Kg} \mathrm{N}$ for maize and wheat plants. The obtained results showed that there were significant effects on grain and straw yields, as well as nutrients concentrations of both maize and wheat plants due to $\mathrm{N}$ sources and rates. In general, Enciabien gave higher grain and straw yields in both maize and wheat crops than ammonium sulfate and ammonium nitrate. Data indicated that rate (100\%) from recommended doses increased significantly yield and nutrients concentrations than other $\mathrm{N}$ doses. The present results focused highlight on the practical importance of adequate $\mathrm{N}$ fertilization and different rates of $\mathrm{N}$ source on (grain and stover) yields and (grain and straw) yields in maize and wheat crops and suggest that Enciabien application at $(100 \%) \mathrm{N}$ from recommended doses will be about adequate to meet crop $\mathrm{N}$ requirements. The obtained results indicated that the concentration of $\mathrm{N}, \mathrm{P}$ and $\mathrm{K}$ in (grain and stover); (grain and straw) of maize and wheat plants were clearly significantly higher under the application of Enciabien fertilizer followed by ammonium sulphate and lately ammonium nitrate. On the other hand, plants received Enciabein at rate of $(100 \%) \mathrm{N}$ from recommended doses showed significantly effect on $\mathrm{Fe}, \mathrm{Mn}, \mathrm{Zn}$ and $\mathrm{Cu}$ concentration than those received ammonium sulphate or ammonium nitrate fertilizer at the same rate. The residual nitrogen in the soil was significantly increased with application of nitrogen fertilizer. It was noted that plots that received $(100 \%) \mathrm{N}$ from recommended doses significantly retained more nitrogen and was higher by 12.3 and $5.9 \%$, respectively than application rates of $(50 \%$ and $75 \%) \mathrm{N}$ from recommended doses. It is worthy to notice that ammonium sulphate yielded the highest values of soil available nitrogen than ammonium nitrate and Enciabein. But, the residual phosphorus and potassium in the soil were significantly decreased with increased application rate of nitrogen fertilizer. The results indicated that the use of ammonium sulphate surpassed the ammonium nitrate and Enciabein in increasing soil available phosphorus and potassium. The available concentration of $\mathrm{Fe}, \mathrm{Mn}, \mathrm{Zn}$ and $\mathrm{Cu}$ in soil significantly increased with different $\mathrm{N}$ rates application. While the application of ammonium sulphate fertilization caused higher relative increase in available concentration of $\mathrm{Fe}, \mathrm{Mn}, \mathrm{Zn}$ and $\mathrm{Cu}$ compared to ammonium nitrate or Enciabein. Inoculation with PGPR caused relative increase for grain and stover yield of maize which recorded 3.93 and $0.97 \%$ for grain and 4.9 and $1.7 \%$ for straw yield of wheat. The available macro and micro-nutrients in soil after harvesting both maize and wheat crops were increased with PGPR inoculation.

Keywords: Nitrogen, source, rate, PGPR inoculation, maize, wheat.

\section{INTRODUCTION}

Maize (Zea mays, L.) is a member of the family Poaceae. It was originated in Mexico where its oldest known ears could be traced back to about 7000 years ago. In world production, maize is ranked as the third major cereal crop after wheat and rice. The crop has a wider range of uses. These uses include the following: human food, industrial processed food production of starch and used as forage to feed animals. Maize with its large number of cultivars and different maturity periods has wider range of tolerance to different environmental conditions (Purseglove, 1972). Wheat is considered a major cereal crop in the world in respect of the cultivated area and total production. It provides an almost $20 \%$ of food calories for people in the world as well as in Egypt. Increasing wheat production as the ultimate goal to reduce the wide gap between production and consumption. Wheat cultivars differed in growth characters, yield and its components (Ahmed et al., 2009).

Nitrogen is the most important nutrient supplied to most non-legume crops, including corn. The most important role of $\mathrm{N}$ in the plant is its presence in the structure of protein and nucleic acids, which are the most important building and information substances of every cell. In addition, $\mathrm{N}$ is also found in chlorophyll that enables the plant to transfer energy from sunlight by photosynthesis. So, N supply to the plant will influence the amount of protein, amino acids, protoplasm, and chlorophyll formed. Moreover, it influences cell size, leaf area, and photosynthetic activity (Namvar and Khandan, 2015). Best nitrogen management practices play an important role in increasing crop productivity. Best nitrogen management practices minimize $\mathrm{N}$ losses and increases $\mathrm{N}$ availability for crops which increase nitrogen use efficiency and reduce negative impacts of $\mathrm{N}$ on the environment, $\mathrm{N}$ use efficiency (NUE) decreases with increase in $\mathrm{N}$ rate and the NUE was higher with application of ammonium sulfate over ammonium nitrate and urea (Amanullah, 2016).

The efficiency of nitrogenous fertilizers use can be increased through using slow-release nitrogen fertilizer, which potentially reduces nitrogen losses either by leaching or volatilization of ammonia and also provide a constant supply of adequate nutrients through the roots (Diez et al., 1994). The extended period of nutrient release may also reduce the need for frequent fertilizer applications, thus reducing labor expenses (Maynard and Lorenz, 1979). It is known that slow-release $\mathrm{N}$ fertilizers are excellent alternative to soluble fertilizer. Nutrients are released at a slower rate throughout the season and the plants are able to absorption most of the nutrients without waste by leaching under sandy soil conditions. In this concern, El-Kramany (2001) found that the use of slowrelease $\mathrm{N}$ fertilizer gave the highest grain yield per plant, 
grain yield per unit area and grain protein content compared to the other $\mathrm{N}$ sources in sandy soil.

The aim of the present study was to evaluate the response of maize and wheat plants to different sources and rates of $\mathrm{N}$ fertilizer as well as soil fertility and enzyme activity after harvesting under inoculation with or without PGPR (plant growth promoting rhizobacteria).

\section{MATERIALS AND METHODS}

The experiment was carried out in the Agricultural research station of EL-Nubaria, El-Behira Governorate, which is located in the North Western of Egypt. (longitudes $30^{\circ} 10^{\prime}$ and latitudes $30^{\circ} 52^{\prime}$ ), during the growing summer and winter seasons 2015/2016. Chemical and physical analyses of the soil $(0-30 \mathrm{~cm})$, were Tabulated in Table (1).

Table 1. Some chemical and physical properties of soil under investigation.

\begin{tabular}{|c|c|c|c|}
\hline Properties & Value & Properties & Value \\
\hline Sand (\%) & 54.0 & \multicolumn{2}{|c|}{ Available micr-onutrient $\left(\mathrm{mg} \mathrm{kg}^{-1}\right)$} \\
\hline Silt (\%) & 16.0 & $\mathrm{Fe}$ & 11.4 \\
\hline Clay $(\%)$ & 30.0 & $\mathrm{Mn}$ & 8.2 \\
\hline Texture & Sand clay loamy & $\mathrm{Zn}$ & 0.85 \\
\hline SP & 31.2 & $\mathrm{Cu}$ & 0.61 \\
\hline $\mathrm{CaCO}_{3}(\%)$ & 41.6 & \multicolumn{2}{|c|}{ Soluble ions $\left(\mathrm{mmol}_{\mathrm{c}} \mathrm{c}^{-1}\right)$} \\
\hline $\mathrm{EC}(\mathrm{dS} / \mathrm{m})$ & 3.44 & $\mathrm{Ca}^{++}$ & 9.5 \\
\hline $\mathrm{pH}$ & 8.12 & $\mathrm{Mg}^{++}$ & 8.0 \\
\hline $\mathrm{O} . \mathrm{M}(\%)$ & 1.14 & $\mathrm{Na}^{+}$ & 13.6 \\
\hline \multicolumn{2}{|c|}{ Available macro-nutrients $\left(\mathrm{mg} \mathrm{kg}^{-1}\right)$} & $\mathrm{K}^{+}$ & 1.44 \\
\hline $\mathrm{N}$ & 63.2 & $\mathrm{HCO}_{3}^{-}$ & 3.5 \\
\hline$P$ & 1.42 & $\mathrm{Cl}^{-}$ & 24.3 \\
\hline K & 370.5 & $\mathrm{SO}_{4}^{-}$ & 4.74 \\
\hline
\end{tabular}

The concurrent studies were conducted to evaluate maize and wheat response to different sources and rates of mineral $\mathrm{N}$ fertilizers under inoculation with or without PGPR (plant growth promoting rhizobacteria) (Azospirrilum spp). The treatments were arrangement on split plot design with three replicates; $\mathrm{N}$ fertilizer source as the main plot and $\mathrm{N}$ rates as the sub-plot. Seeds of maize and wheat were coated with $20 \%$ arabic gum as an adhesive and inoculated with 7 gram inoculation with PGPR including $10^{7}$ alive and active bacteria before planting.

The different sources and rates of nitrogen fertilizer, i.e., ammonium sulphate $(20.6 \% \mathrm{~N})$, ammonium nitrate $(33.5 \% \mathrm{~N})$, and Enciabien, $40 \% \mathrm{~N}$ (slow-release) with or without inoculation by (plant growth promoting rhizobactteria) (PGPR); were applied at three rates of (50, 75 and $100 \%)$.from recommended doses of minerals nitrogen (60, 90 and 120) and (40,60 and 80) $\mathrm{Kg} \mathrm{N}$ for maize and wheat plants; the amount applied of different $\mathrm{N}$ fertilizer source, i.e., were (292.7, 439.0 and 585.4) \& (1951, 292.7 and 390.2) from ammonium sulphate (20.6\% $\mathrm{N})$; (179.1, 268.7 and 358.2); (119.4, 179.1 and 238.8) form ammonium nitrate $(33.5 \% \mathrm{~N})$ and $(125.0,187.5$ and 250.0) and (83.3, 125.0 and $\left.166.7 \mathrm{Kg} \mathrm{fed}^{-1}\right)$ from Enciabien, $(40 \% \mathrm{~N})$ for maize and wheat plants respectively.

Different nitrogen sources were addition at two equal doses; the first 30 days from sowing and the second at 25 days after the first addition. Phosphorus fertilizer, in the form of Super phosphate $\left(15 \% \mathrm{P}_{2} \mathrm{O}_{5}\right)$, was applied at with soils preparation at the rate of $147 \mathrm{~kg} \mathrm{P}_{2} \mathrm{O}_{5} \mathrm{fed}^{-1}$. Potassium fertilizer was added as potassium sulphate (48\% $\mathrm{K}_{2} \mathrm{O}$ ) at the rate of $50.40 \mathrm{~kg} \mathrm{~K}_{2} \mathrm{O}$ fed $^{-1}$ with the second dose of $\mathrm{N}$ fertilizer.

Maize (Zea mays L.) plants varieties triple hybrid, 321 was the preceding summer crop. Seeds of maize sown on $4{ }^{\text {st }}$ week of July 2016. Each plot consisted of 4 rows, $3.5 \mathrm{~m}$ long, $0.3 \mathrm{~m}$ width and $0.6 \mathrm{~m}$ between rows, giving a plot area of $10.5 \mathrm{~m}^{2}$. Seeds were sown in hills, $20 \mathrm{~cm}$ apart. Each row contained 15 plants after thinning to one plant per hill. At the end of the experiment (120 days), maize plants were harvested; random samples were taken for analysis. Wheat (Triticum aestivum L.) plants varieties Sakha 69 was the winter crop was sown on the 3rd week of November 2016/2017. Plots of the same area of $10.5 \mathrm{~m} 2$ were used. After harvesting maize plants, soil surface was flattened in all plots. At the end experiment (180 days), wheat plants were harvested. Random samples from the middle area of each plot were taken (one $\mathrm{m}^{2}$ per plot) from all the treatments to determine plant grain yield $\mathrm{fed}^{-1}$ (ton) and straw yield $\mathrm{fed}^{-1}$ (ton) were determined from the whole area of experimental units for the yield determined and then converted to yield per fed. Three random plants per plot from all the treatments thoroughly washed with tap water followed by distilled water, dried in an oven at $70^{\circ} \mathrm{C}$ for $72 \mathrm{hrs}$ and grounded in stainless steel mill. The fine ground was prepared as half gram of dry matter was wet digested by using a mixture of sulphuric and percloric acids $\left(\mathrm{HClO}_{4}+\mathrm{H}_{2} \mathrm{SO}_{4}\right)$ acids according to the procedure of Benton (2001). and ICARDA (2013).

Surface soil samples $(0-30 \mathrm{~cm})$ were collected after harvesting the plants, air dried, ground, good mixed, sieved through a $2 \mathrm{~m}$ sieve and analyzed for some chemical and physical properties. According to ICARDA (2013), the following measurements and determinations were made: particle size distribution was carried out using the pipette method; electrical conductivity values of soil paste by using electrical conductivity meter model WTW Series Cond 720 ; soil $\mathrm{pH}$ values in soil suspensions $(1: 2.5)$ by using $\mathrm{pH}$ meter model WTW Series $\mathrm{pH} 720$; soluble cations and anions were carried out in soil samples determinations were made based on the methods described by AOAC (1990); Available nitrogen in soil was extracted using $2 \mathrm{~N} \mathrm{KCl}$ as an extractable solution with the ratio of (5gm soil to $50 \mathrm{ml} \mathrm{KCl}$ ); Available (K, P, Fe, Mn, Zn, and $\mathrm{Cu})$ were extracted according to the method of Soltanpour and Schwab (1991). Available nitrogen in soil and plants were determined by using Automatic micro Kjeldahe Vapodest 30S according to AOAC (1990). Soluble Na and $\mathrm{K}$ in soil; available $\mathrm{K}$ in soils and total $\mathrm{K}$ in plant were determined by flame photometer as described by ICARDA (2013). P, Fe, $\mathrm{Mn}, \mathrm{Zn}$ and $\mathrm{Cu}$ in soils and plants were determined according to Environmental Protection Agency (EPA, 1991) using Inductively Coupled Plasma (ICP) Spectrometry (Ultima 2 JY Plasma). The activity of urease was measured by the method of McGarity and Myers (1967) and dehydrogenase activity was measured by the method of Casida (1977). Statistical analysis was performed according to Snedecor and Cochran (1980). 


\section{RESULTS AND DISCUSSION}

I. Grain and stover of maize plants as affected by rates and sources of nitrogen with or without inoculation.

Grain yield is the main target of crop production.

Data in Table (2) showed that, the grain yield of maize was significantly affected by both $\mathrm{N}$ application source and rates. $\mathrm{N}$ rates significantly increased the grain yield. The grain yield varied between $3.94 \mathrm{~T}^{\mathrm{T}} \mathrm{fed}^{-1}$ with application 50 $\mathrm{kg} \mathrm{N}$ fed $^{-1}$ as ammonium nitrate and $5.62 \mathrm{~T}^{\mathrm{T}} \mathrm{fed}^{-1}$ at application of $100 \mathrm{~kg} \mathrm{~N} \mathrm{fed}^{-1}$ as Enciabien. A similar trend was showed across $\mathrm{N}$ rates has been reported by Zeidan et $a l$. (2006). Data obtained was in agreement with Lawrence et al. (2008) who reported that grain yield increased with increasing $\mathrm{N}$ rates.

Data obtained indicated that, the percentages of relative increase for grain and stover yield of maize were (22.38 and $8.55 \%)$ and (9.85 and $4.25 \%$ ) with application of rate of $100 \%$ compared with $50 \%$ and $75 \% \mathrm{~N}$ from recommended dose, respectively. Sampath et al. (2013) revealed that stover yield in maize increased with increasing $\mathrm{N}$ addition rate. The highest production for grain and stover yields for different $\mathrm{N}$ sources as deciding order Enciabein $>$ ammonium sulfate $>$ ammonium nitrate.The percentages of relative increase were 6.94 and $11.38 \%$ for grain yield with application of Enciabein compared with ammonium sulfate and ammonium nitrate, respectively. While application of Enciabein recorded relative increased 3.93 and $5.85 \%$ compared with ammonium sulfate and ammonium nitrate for the stover yield, respectively. The interaction between nitrogen source and nitrogen rate is indicated that the increase in $\mathrm{N}$ rates increased grain and stover yield of maize with using different $\mathrm{N}$ sources; highest increase for grain and stover yields were of maize at application rate of $100 \% \mathrm{~N}$ from recommended dose were (5.62 and $\left.6.92 \mathrm{t} \mathrm{fed}^{-1}\right)$ for Enciabein; $(5.15$ and $644 \mathrm{t}$ $\left.\mathrm{fed}^{-1}\right)$ for ammonium sulfate and $\left(5.3\right.$ and $\left.6.31 \mathrm{t} \mathrm{fed}^{-1}\right)$ for ammonium nitrate. The percentages of relative increase for grain and stover yields were (5.51, 6.57 and 8.37\%) and $(1.43,3.35$ and $6.64 \%)$ for fertilizes by Enciabein at application rates of (50, 75 and100\%) $\mathrm{N}$ from recommended dose compared with ammonium sulfate; as well as were $(10.20,9.15$ and $10.44 \%)$ and $(2.85,4.83$ and $8.17 \%$ ) compared with ammonium nitrate respectively. In soils calcareous in nature, ammonium sulfate because of its free sulfur content, could be the most beneficial $\mathrm{N}$-fertilizer in terms of soil improvement, higher crop growth, increase in number of leaves plant ${ }^{-1}$, mean single, leaf area plant ${ }^{-1}$ and more dry matter partitioning to leaves. According to Amanullah et al. (2014) ammonium sulfate is the best $\mathrm{N}$ fertilizer source which contains frees sulfur and had many potential agronomic and environmental benefits over ammonium nitrate. The higher transportation charge of ammonium sulfate is also more than ammonium nitrate.

\section{Grain and straw yields of wheat as affected by rates and sources of nitrogen with or without incubation.}

Data in Table (2) showed that the grain and straw yields of wheat was significantly affected by both $\mathrm{N}$ application source and rates. The grain and straw yield of wheat varied between 2.80 and $3.83 \mathrm{t} \mathrm{fed}^{-1}$ with application rate of $50 \% \mathrm{~N}$ from recommended dose as ammonium nitrate and from 3.52 to $4.70 \mathrm{t} \mathrm{fed}^{-1}$ with application of
$(100 \%) \mathrm{N}$ from recommended dose as Enciabien. The percentages of relative increase were (20.33 and $11.94 \%)$ and $(17.90$ and $11.3 \%)$ for grain and straw yields respectively, with application rate of $(100 \%) \mathrm{N}$ from recommended dose compared with (50 and 75\%) $\mathrm{N}$ from recommended doses, respectively. This may be attributed to the favorable effect of the recommended mineral $\mathrm{N}$ fertilizer rate on the metabolic processes and physiological activates of meristimatic tissues, which are responsible for cell division and elongation in addition to formation of plant organs (El-Kramany, 2001). Also, application of Enciabein gave higher productivity for grain and straw yields of wheat plants competed with ammonium sulfate and ammonium nitrate. The deciding order for different nitrogen sources were as the following Enciabein > ammonium sulfate $>$ ammonium nitrate.

The percentages of relative increase for application of Enciabein were (4.96 and 10.52\%) and (4.59 and $9.10 \%$ ) for grain and straw yields compared with ammonium sulfate and ammonium nitrate, respectively. The increases in plant dry weight due to the application of Enciabien form might be due to the role of nitrogen for increase in the bio synthesis of plant hormones or ouxenes such as indol acetic acid (IAA) or Gibberellins (GA3) which increase both cell division and elongation in cell internodes resulted in an increase for plant height. Similar results were reported by Kolhe and Mittra (1989); Zhang et al. (1998) and El-Kramany (2001) showed that slowrelease urea increased wheat yields by $18.3-27.8 \%$ and increased rice yields compared with common urea. Application of $100 \mathrm{~kg} \mathrm{~N} / \mathrm{fed}$ as Enciabien gave the highest grain and straw yields with a significant difference than those produced by 50 or $75 \mathrm{~kg} \mathrm{~N}^{-1}$. (Hanan Taha, 2008.and Metwally et al., 2011).

The interaction between $\mathrm{N}$ sources and rates had significant effects on grain and straw yields of wheat, indicating that the grain and straw yields of wheat were increased to maximum level with Enciabein applied at rate of $(100 \%) \mathrm{N}$ from recommended dose $\mathrm{fed}^{-1}$ the highest grain and straw yield were $\left(3.74\right.$ and $\left.4.91 \mathrm{t} \mathrm{fed}^{-1}\right)$ with applied Enciabein and $\left(3.61\right.$ and $\left.4.78 \mathrm{t} \mathrm{fed}^{-1}\right)$, with applied ammonium sulfate; and were (3.39 and $\left.4.56 \mathrm{t} \mathrm{fed}^{-1}\right)$, with applied ammonium nitrate, respectively. The percentages of relative increase were $(4.30,5.65$ and $4.86 \%)$ for grain yield and (4.56, 6.84 and $2.58 \%$ ) for straw yield, with application of Enciabein at rates of 50,75 and $100 \mathrm{~kg} \mathrm{~N}$ fed $^{-1}$ compared with ammonium sulfate at the same rate, respectively; As well as $(6.87,10.69$ and $10.0 \%)$ and $(9.74$, 7.75 and $6.49 \%$ ) in grain and straw yields with used Enciabein fertilizer, compared with ammonium nitrate at the same rate, respectively.

Finally, data recorded that, yield of maize and wheat was significantly affected by PGPR application. The percentages of relative increase were 3.93 and $0.97 \%$ for grain and stover yields of maize which were 4.9 and $1.7 \%$ for grain and straw yield of wheat with application of PGPR compared with that without inoculation treatments, respectively. These results could be due to the effect of biofertilizers on biological nitrogen fixation, production of growth hormones (auxin) and secretion of antibiotics leading to the development of root systems, which increased the vegetative growth and yield. These results 
obtained were similar to the results of Cavender et al. (2003). They reported that bio-fertilizers when added with nitrogen fertilizers increased the plant's component functions and biological functions of maize plant by activating the soil's useful microorganism activities and persistent feeding of mineral elements especially nitrogen for the plant.

Table 2. Effect of different nitrogen fertilizer sources and rates on some yield parameters of maize and wheat plants under inoculation with or without PGPR.

\begin{tabular}{|c|c|c|c|c|c|c|}
\hline \multirow{3}{*}{$\begin{array}{l}\text { PGPR } \\
\text { (A) }\end{array}$} & \multirow{3}{*}{$\begin{array}{c}\text { Source } \\
\text { of } \mathbf{N} \\
\text { (B) }\end{array}$} & \multirow{3}{*}{$\begin{array}{l}\text { The percentage of } \\
\text { recommended doses } \\
\text { (C) }\end{array}$} & \multicolumn{2}{|c|}{ Maize } & \multicolumn{2}{|c|}{ Wheat } \\
\hline & & & \multirow{2}{*}{\multicolumn{4}{|c|}{ (T.fed ${ }^{-1}$.) }} \\
\hline & & & & & & \\
\hline \multirow{12}{*}{ With inoculation } & \multirow{4}{*}{$(\mathrm{NH} 4)_{2} \mathrm{SO}_{4}$} & $50 \%$ & 4.17 & 5.93 & 2.88 & 3.90 \\
\hline & & $75 \%$ & 4.82 & 6.24 & 3.20 & 4.11 \\
\hline & & $100 \%$ & 5.15 & 6.44 & 3.61 & 4.78 \\
\hline & & Mean & 4.71 & 6.20 & 3.23 & 4.26 \\
\hline & \multirow{4}{*}{$\mathrm{NH}_{4} \mathrm{NO}_{3}$} & $50 \%$ & 3.94 & 5.81 & 2.79 & 3.69 \\
\hline & & $75 \%$ & 4.74 & 6.12 & 2.99 & 4.06 \\
\hline & & $100 \%$ & 5.03 & 6.31 & 3.39 & 4.56 \\
\hline & & Mean & 4.57 & 6.08 & 3.06 & 4.10 \\
\hline & \multirow{4}{*}{ Enciabien } & $50 \%$ & 4.31 & 5.98 & 2.97 & 4.07 \\
\hline & & $75 \%$ & 5.04 & 6.45 & 3.31 & 4.43 \\
\hline & & $100 \%$ & 5.62 & 6.92 & 3.74 & 4.91 \\
\hline & & Mean & 4.99 & 6.45 & 3.34 & 4.47 \\
\hline \multirow{12}{*}{$\begin{array}{l}\text { Without } \\
\text { inoculation }\end{array}$} & \multirow{4}{*}{$(\mathrm{NH} 4)_{2} \mathrm{SO}_{4}$} & $50 \%$ & 3.89 & 5.82 & 2.69 & 3.84 \\
\hline & & $75 \%$ & 4.57 & 6.16 & 2.98 & 4.06 \\
\hline & & $100 \%$ & 5.03 & 6.36 & 3.43 & 4.67 \\
\hline & & Mean & 4.49 & 6.11 & 3.03 & 4.19 \\
\hline & \multirow{4}{*}{$\mathrm{NH}_{4} \mathrm{NO}_{3}$} & $50 \%$ & 3.72 & 5.77 & 2.63 & 3.63 \\
\hline & & $75 \%$ & 4.39 & 6.09 & 2.86 & 4.03 \\
\hline & & $100 \%$ & 4.92 & 6.28 & 3.27 & 4.51 \\
\hline & & Mean & 4.34 & 6.05 & 2.92 & 4.06 \\
\hline & \multirow{4}{*}{ Enciabien } & $50 \%$ & 4.22 & 5.94 & 2.85 & 4.04 \\
\hline & & $75 \%$ & 5.01 & 6.38 & 3.24 & 4.34 \\
\hline & & $100 \%$ & 5.49 & 6.79 & 3.66 & 4.79 \\
\hline & & Mean & 4.91 & 6.37 & 3.25 & 4.39 \\
\hline \multicolumn{7}{|l|}{$\overline{\mathrm{LSD}}$ at 0.05} \\
\hline B & & & 0.61 & 0.24 & 0.21 & 0.53 \\
\hline$A \times B$ & & & 0.51 & 0.20 & 0.18 & 0.45 \\
\hline $\mathrm{C}$ & & & 0.59 & 0.39 & 0.29 & 0.60 \\
\hline$A \times C$ & & & 0.49 & 0.33 & 0.24 & 0.50 \\
\hline $\mathrm{B} \times \mathrm{C}$ & & & 0.54 & 0.37 & 0.27 & 0.55 \\
\hline $\mathrm{A} \times \mathrm{B} \times \mathrm{C}$ & & & 0.70 & 0.47 & 0.35 & 0.72 \\
\hline
\end{tabular}

III. Effect of N-rates on macro and micro-nutrients concentration in grain and stover of maize plant.

The obtained data in Table (3) showed that increasing nitrogen fertilizer rates led to a significant increase in $\mathrm{N}, \mathrm{P}$ and $\mathrm{K}$ concentration in grain and stover yields of maize plant. These results may be due to the role of nitrogen in stimulating building of amino acids and growth hormones. This is turn into positively effect on cell division and enlargement; also nitrogen fertilizer may be promoting change in mineral composition of plant Mengel and Kirkby (1982). Application nitrogen fertilizer at $(100 \%) \mathrm{N}$ from recommended dose $\mathrm{fed}^{-1}$ gave the highest values for $\mathrm{N}, \mathrm{P}$ and $\mathrm{K}$ concentration by grain and stover of maize crop.

Furthermore, data in Table (3) showed also when applied $\mathrm{N}$ at $120 \mathrm{~kg} \mathrm{~N}$ fed $^{-1}$ significantly increased $\mathrm{N}, \mathrm{P}$ and $\mathrm{K}$ concentration for grain and stover yield of maize crop then 60 and $90 \mathrm{~kg} \mathrm{~N} \mathrm{fed}^{-1}$ fertilizer. These results may be due to the variation of level of nitrogen which it reflect that a higher absorption of nitrogen by maize plant from soil. Generally, the highest value of $\mathrm{N}, \mathrm{P}$ and $\mathrm{K}$ concentration resulted when application of $120 \mathrm{~kg} \mathrm{~N} \mathrm{fed}^{-1}$ fertilizer whereas, the lowest value when application of 60 $\mathrm{kg} \mathrm{N} \mathrm{fed}{ }^{-1}$. The relative increasing of $\mathrm{N}, \mathrm{P}$ and $\mathrm{K}$ concentration due to application of $120 \mathrm{~kg} \mathrm{~N}$ fed $^{-1}$ over 60 and $90 \mathrm{~kg} \mathrm{~N}^{-1}$ were $(18.28,10.84$ and $22.19 \%)$ and $(13.43,4.82$ and $10.93 \%)$ in grain of maize compared with 60 and $90 \mathrm{~kg} \mathrm{~N}^{-1} \mathrm{fed}^{-1}$, while were $(24.15,417.14$ and $24.17 \%$ ) and (11.76, 9.52 and $16.11 \%$ ) compared with the same rate $\mathrm{kg} \mathrm{N}_{\text {fed }}{ }^{-1}$ in stover of maize plants, respectively.

The obtained data in Table (3) showed that inoculation with PGPR led to a significantly increase in N, $\mathrm{P}$ and $\mathrm{K}$ concentration in grain and stover yield of maize plant. The relative increasing of $\mathrm{N}, \mathrm{P}$ and $\mathrm{K}$ concentration in grain and stover of maize yields, due to application of PGPR were $(5.46,4.15$ and $6.07 \%$ ) in grain and $(8.52$, 2.07 and $2.11 \%$ ) in stover compared with un-inoculation with PGPR of maize plants, respectively. The results are in harmony with those obtained by Meshram and Shende (1993) who suggested that PGPR increases root surface area and thus promotes intake of $\mathrm{N}, \mathrm{P}, \mathrm{K}$ and other nutrients and also water and consequently above ground part weight of plants.

Data in Table (3) showed that the effect of application of different sources and rates of nitrogen on the concentration of $\mathrm{Fe}, \mathrm{Mn}, \mathrm{Zn}$ and $\mathrm{Cu}$ in grain and stover of 
maize crop. The relative increases may be due to application of $120 \mathrm{Kg} \mathrm{N}_{\text {fed }}{ }^{-1}$ over 60 and $90 \mathrm{Kg} \mathrm{N}$ fed $^{-1}$. The relative increase of $\mathrm{Fe}, \mathrm{Mn} \mathrm{Zn}$ and $\mathrm{Cu}$ were (22.90, $20.97,18.55$ and $34.34 \%)$ and $(13.59,8.36,8.81$ and $15.85 \%)$ in grain and $(20.88,23.89,22.54$ and $28.33 \%)$ and $(12.55,10.68,11.25$ and $15.15 \%)$ in stover compared with (60 and $90 \mathrm{~kg} \mathrm{~N}$ fed $\left.^{-1}\right)$, respectively.

\section{Effect of $\mathrm{N}$-sources on macro and micronutrients} concentration in grain and stover of maize plant:

Data in Table (3) showed that the values of N, P and $\mathrm{K}$ concentration in grain and stover of maize plants were generally significantly affected by different sources of $\mathrm{N}$. The higher values of $\mathrm{N}, \mathrm{P}$ and $\mathrm{K}$ concentration in straw and grain yield were found when application of Enciabein was used than the other forms of N. It was found that application of Enciabein gave higher values than ammonium sulphate and ammonium nitrate in decreasing order. These results may be attributed to the influence of such $\mathrm{N}$ sources on plant growth. Our results are in harmony with those obtained by Kumar et al. (1986). Also, it might be due to high exchange capacity of plant roots supplied with $\mathrm{N}$ fertilizer in building metabolites which might contribute much to increase the dry matter yields and nutrients uptake by plants. In general, the recent maize production practices involve using balanced amount of $\mathrm{N}$, $\mathrm{P}$ and $\mathrm{K}$ for optimum yield and quality. This result may be due to the regulation of nutrient release and enhancement the nitrogen use efficiency by plants with slow-release $\mathrm{N}$ fertilizer than uncoated fertilizer and subsequently reducing-N leaching losses and provide a constant supply of nutrients to the roots (El-Aila et al., 2001). Similar results were obtained by Abd El-Hameed (2002) and Ahmed et al. (2009).

The relative increases for $\mathrm{N}, \mathrm{P}$ and $\mathrm{K}$ concentration in grain and stover fertilized by use Enciabein was more than ammonium sulphate it were (7.69, 1.24 and $13.42 \%)$; and $(16.65,14.15$ and $9.49 \%)$, as well as were (14.62, 5.59 and $21.09 \%)$ in grain $(19.70,16.04$ and $14.46 \%)$ in stover, compared with ammonium nitrate, respectively. On the other hand, plants fertilized by Enciabein showed significantly higher of Fe, Mn Zn and $\mathrm{Cu}$ concentration in maize plant than those fertilized by ammonium sulphate or ammonium nitrate fertilizer, this may be due to increase in utilization coefficient of Enciabein as a source of nitrogen form. Also, Enciabein as the nitrogen source may promote changes in the mineral composition of plant. Generally, the highest content values of $\mathrm{Fe}, \mathrm{Mn} \mathrm{Zn}$ and $\mathrm{Cu}$ in maize plant which were obtained by using Enciabein followed by ammonium sulphate and ammonium nitrate in decreasing order.

The relative increases of $\mathrm{Fe}, \mathrm{Mn} \mathrm{Zn}$ and $\mathrm{Cu}$ content for applied Enciabein were $(22.54,14.55,14.88$ and $21.32 \%)$ in grain of maize yield and were $(7.00,6.86,6.89$ and $12.61 \%$ ) in stover yield compared with ammonium sulphate and were $(27.91,21.08,21330$ and 24.81\%) in grain of maize yield and were $(11.80,10.93,11.33$ and $17.51 \%$ ) in stover yield compared with ammonium nitrate respectively. The use of Enciabein fertilizer gave the highest concentration of $\mathrm{Fe}, \mathrm{Mn}, \mathrm{Zn}$ and $\mathrm{Cu}$ in grain and stover of maize crop This may be due to the superiority of Enciabein as nitrogen form in grain and stover yields might be ascribed to increase in the studied components of grain and stover yields, moreover, applying ammonium nitrate gave the lowest values. This result could be explained by the promotive effect of Enciabein on maize growth which consequently enhanced its ability to nutrients uptake. Similar results were obtained by Murillo et al. (1992). On the other hand, Sarhan et al. (2004) stated that the application of all nitrogen forms caused an increase of $\mathrm{Zn}$ concentration in leaf tissues, but this increase was not significant with zinc. This may attributed to the dilution effect which decreased $\mathrm{Zn}$ concentration in the leaf tissues.

Data in Table (3) showed the effect of PGPR application on the concentration of $\mathrm{Fe}, \mathrm{Mn}, \mathrm{Zn}$ and $\mathrm{Cu}$ in stover and grain of maize crop. The relative increased of $\mathrm{Fe}, \mathrm{Mn} \mathrm{Zn}$ and $\mathrm{Cu}$ concentration due to application of PGPR were $(7.84,6.10,5.31$ and $4.14 \%)$ and (3.92, 4.47, 7.67 and $5.84 \%$ ) for grain and stover of maize plants respectively; compared with that un-inoculation with PGPR,.

IIV. Effect of interaction between rates and sources of nitrogen application on macro and micronutrients concentration in grain and stover of maize plants.

Data presented in Table (3) showed that the interaction between application of nitrogen rates and sources was significantly affected N, P and K concentration in maize plant. The addition of Enciabein at rates of 50,75 and $100 \% \mathrm{~N}$ from recommended dose increased $\mathrm{N}, \mathrm{P}$ and $\mathrm{K}$ concentration than the addition of different sources of each applied $\mathrm{N}$ rate. The average increase for macro-nutrients in grain and stover of maize plant with use Enciabein compared with the addition of ammonium sulphate fertilizer were $(12.29,7.39$ and $4.08 \%)$ and $(14.35,20.51$ and 14.78) for $\mathrm{N} ;(1.96,3.64$ and $3.45 \%)$ and (15.63, 14.29 and 12.82) for $\mathrm{P}$ and $(9.20,12.50$ and $17.21 \%)$ and $(2.73,3.66$ and 18.79$)$ for $\mathrm{K}$, When rates add $(50 \% ; 75 \%$ and $100 \%) \mathrm{N}$ from recommended dose respectively; as well as the average increases at the same rates for Enciabein compared with the addition of ammonium nitrate fertilizer, were $(14.71,12.79$ and $14.73 \%)$ and $(16.59,23.81$ and 13.40) for $\mathrm{N}(5.88,7.27$ and $8.62 \%)$ and (12.50, 14.29 and 17.95) for $\mathrm{P}$ and (12.64, 21.50 and $27.87 \%)$ and $(14.85,5.92$ and 15.77$)$ for $K$, respectively. It could to be that the result emphasized the superiority of Enciabein fertilizer than other treatments, further more $\mathrm{N}$ plays a vital role in nutrition and physiological status in plants and unique among the mineral nutrients that absorbed as $\mathrm{NO}_{3}$ and $\mathrm{NH}_{4}$ ions.

The addition of Enciabein at rates of $(50,75$ and $100 \%) \mathrm{N}$ from recommended dose increased micronutrients than the addition of different sources for each $\mathrm{N}$ rate. The average increases for ( $\mathrm{Fe}, \mathrm{Mn}, \mathrm{Zn}$ and $\mathrm{Cu}$ ) in (grain) and (stover) with addition of Enciabein compared with addition of ammonium sulphate, were $(22.13,15.10$, 18.48 and 18.18\%); (7.96, 12.03, 6.98 and 11.83\%) at addition rate of $(50 \%) \mathrm{N}$ from recommended dose, as well as at addition rate of $(75 \%) \mathrm{N}$ from recommended dose were $(23.03,15.64,12.88$ and $25.56 \%)$ and $98.95,5.59$, 4.76 and $10.50 \%)$; while at addition rate of $(100 \%) \mathrm{N}$ from recommended dose were $(22.44,13.08,13.64$ and 19.61) and (4.46, 3.86, 8.67 and 14.87), respectively. As well as the average increases for $(\mathrm{Fe}, \mathrm{Mn}, \mathrm{Zn}$ and $\mathrm{Cu}$ ) with use Enciabein as compared with the addition of ammonium 
nitrate at the same rates $(50,75$ and $100 \%) \mathrm{N}$ from recommended dose were $(28.62,21.78,25.08$ and $18.18 \%)$; (26.75, 22.13, 20.25 and 26.67\%) and (27.01, $16.30,15.34$ and $20.59 \%)$, for grain and were $(10.50$, $12.83,10.91$ and $13.44 \%)$; (12.38, 8.90, 8.41 and $13.24 \%)$ and $(8.16,6.01,11.28$ and $20.07 \%)$ for stover, respectively. These results are attributed to changes in $\mathrm{pH}$ when ammonium $\mathrm{N}$ is absorbed, plants release protons causing the growth media to be more acidic and nutrient availability media is increased These results are in agreement with those obtained by Darwish (1998) and Gupta and Polalia (1991) who stated that ammonium, sulphate fertilizer was more effective in increasing the maize yield, Fe and Mn contents and its uptake by plants. The rhizosphere acidification from nitrogen supply as well as of the plant factors (enhanced net excretion of protons or organic acids) are of particularly importance for acquisition of Fe, $\mathrm{Zn}$ and $\mathrm{Mn}$ in alkaline soils (Wenming et al., 2001).

Table 3. Effect of different nitrogen fertilizer sources and rates on macro and micro-nutrients content of maize stover and wheat straw under inoculation with or without PGPR.

\begin{tabular}{|c|c|c|c|c|c|c|c|c|c|c|c|c|c|c|c|c|}
\hline \multirow{3}{*}{$\begin{array}{l}\text { PGPR } \\
\text { (A) }\end{array}$} & \multirow{3}{*}{$\begin{array}{c}\mathbf{N} \\
\text { Sources } \\
\text { (B) }\end{array}$} & \multirow{3}{*}{$\begin{array}{c}\text { The } \\
\text { percentage of } \\
\text { recommended } \\
\text { doses }(C)\end{array}$} & \multicolumn{7}{|c|}{ Maiz grain } & \multicolumn{7}{|c|}{ Maiz stover } \\
\hline & & & $\mathbf{N}$ & $\mathbf{P}$ & $\mathbf{K}$ & Fe & Mn & Zn & $\mathrm{Cu}$ & $\mathbf{N}$ & $\mathbf{P}$ & $\mathbf{K}$ & $\mathbf{F e}$ & Mn & Zn & $\mathrm{Cu}$ \\
\hline & & & \multicolumn{3}{|c|}{$(\%)$} & \multicolumn{4}{|c|}{$\left(\mathrm{mg} \mathrm{kg}^{-1}\right)$} & \multicolumn{3}{|c|}{$(\%)$} & \multicolumn{4}{|c|}{$\left(\mathrm{mg} \mathrm{kg}^{-1}\right)$} \\
\hline \multirow{12}{*}{$\begin{array}{l}\text { With } \\
\text { inoculation }\end{array}$} & \multirow{4}{*}{$(\mathrm{NH} 4)_{2} \mathrm{SO}_{4}$} & $50 \%$ & 2.48 & 0.25 & 0.41 & 48.70 & 35.40 & 12.70 & 2.80 & 1.15 & 0.16 & 1.68 & 190.60 & 57.90 & 29.40 & 9.70 \\
\hline & & $75 \%$ & 2.63 & 0.27 & 0.47 & 52.90 & 40.20 & 14.80 & 3.40 & 1.41 & 0.18 & 1.79 & 212.00 & 64.80 & 32.30 & 11.70 \\
\hline & & $100 \%$ & 3.18 & 0.28 & 0.51 & 61.70 & 44.60 & 15.40 & 4.20 & 1.50 & 0.20 & 2.35 & 236.00 & 70.40 & 37.50 & 14.20 \\
\hline & & Mean & 2.76 & 0.27 & 0.46 & 54.40 & 40.10 & 14.30 & 3.50 & 1.35 & 0.18 & 1.61 & 212.90 & 64.40 & 33.10 & 11.90 \\
\hline & \multirow{4}{*}{$\mathrm{NH}_{4} \mathrm{NO}_{3}$} & $50 \%$ & 2.40 & 0.24 & 0.38 & 44.60 & 33.00 & 11.50 & 2.70 & 0.93 & 0.13 & 1.60 & 169.00 & 48.00 & 24.80 & 8.00 \\
\hline & & $75 \%$ & 2.46 & 0.26 & 0.42 & 50.40 & 37.80 & 13.30 & 3.40 & 0.98 & 0.15 & 1.69 & 184.70 & 57.90 & 29.10 & 9.70 \\
\hline & & $100 \%$ & 2.79 & 0.27 & 0.45 & 59.80 & 42.00 & 15.00 & 4.10 & 1.20 & 0.17 & 1.84 & 218.00 & 66.20 & 31.80 & 11.20 \\
\hline & & Mean & 2.55 & 0.26 & 0.42 & 51.60 & 37.60 & 13.30 & 3.40 & 1.04 & 0.15 & 1.71 & 190.60 & 57.40 & 28.60 & 9.60 \\
\hline & \multirow{4}{*}{ Enciabien } & $50 \%$ & 2.70 & 0.27 & 0.46 & 62.80 & 41.60 & 15.70 & 3.40 & 0.92 & 0.14 & 1.40 & 165.40 & 47.60 & 23.40 & 8.00 \\
\hline & & $75 \%$ & 2.83 & 0.29 & 0.54 & 70.40 & 49.20 & 16.90 & 4.60 & 0.96 & 0.15 & 1.66 & 179.00 & 55.80 & 28.00 & 9.40 \\
\hline & & $100 \%$ & 3.27 & 0.31 & 0.64 & 81.60 & 51.70 & 18.30 & 5.20 & 1.18 & 0.16 & 1.94 & 210.00 & 64.70 & 30.70 & 10.60 \\
\hline & & Mean & 2.93 & 0.28 & 0.54 & 71.60 & 47.50 & 16.90 & 4.40 & 1.02 & 0.15 & 1.67 & 184.80 & 56.00 & 27.40 & 9.30 \\
\hline \multirow{12}{*}{$\begin{array}{l}\text { Without } \\
\text { inoculation }\end{array}$} & \multirow{4}{*}{$(\mathrm{NH} 4)_{2} \mathrm{SO}_{4}$} & $50 \%$ & 2.23 & 0.25 & 0.38 & 44.90 & 33.20 & 12.00 & 2.60 & 1.08 & 0.16 & 1.62 & 186.40 & 54.30 & 26.50 & 8.90 \\
\hline & & $75 \%$ & 2.51 & 0.26 & 0.44 & 50.40 & 39.10 & 13.60 & 3.30 & 1.32 & 0.17 & 1.76 & 209.00 & 62.10 & 30.70 & 10.20 \\
\hline & & $100 \%$ & 2.94 & 0.28 & 0.50 & 58.60 & 41.80 & 15.00 & 4.00 & 1.41 & 0.19 & 2.28 & 230.80 & 69.40 & 35.20 & 12.70 \\
\hline & & Mean & 2.56 & 0.26 & 0.44 & 51.30 & 38.00 & 13.50 & 3.30 & 1.27 & 0.17 & 1.89 & 208.70 & 61.90 & 30.80 & 10.60 \\
\hline & \multirow{4}{*}{$\mathrm{NH}_{4} \mathrm{NO}_{3}$} & $50 \%$ & 2.18 & 0.24 & 0.38 & 41.20 & 30.20 & 11.20 & 2.70 & 1.15 & 0.16 & 1.68 & 190.60 & 57.90 & 29.40 & 9.70 \\
\hline & & $75 \%$ & 2.38 & 0.25 & 0.40 & 47.90 & 35.40 & 12.70 & 3.20 & 1.41 & 0.18 & 1.79 & 212.00 & 64.80 & 32.30 & 11.70 \\
\hline & & $100 \%$ & 2.65 & 0.26 & 0.43 & 53.40 & 41.20 & 14.80 & 4.00 & 1.50 & 0.20 & 2.35 & 236.00 & 70.40 & 37.50 & 14.20 \\
\hline & & Mean & 2.40 & 0.25 & 0.40 & 47.50 & 35.60 & 12.90 & 3.30 & 1.35 & 0.18 & 1.61 & 212.90 & 64.40 & 33.10 & 11.90 \\
\hline & \multirow{4}{*}{ Enciabien } & $50 \%$ & 2.67 & 0.24 & 0.41 & 57.40 & 39.20 & 14.60 & 3.20 & 0.93 & 0.13 & 1.60 & 169.00 & 48.00 & 24.80 & 8.00 \\
\hline & & $75 \%$ & 2.72 & 0.26 & 0.50 & 63.80 & 44.80 & 15.70 & 4.40 & 0.98 & 0.15 & 1.69 & 184.70 & 57.90 & 29.10 & 9.70 \\
\hline & & $100 \%$ & 3.11 & 0.27 & 0.58 & 73.50 & 47.70 & 16.90 & 5.00 & 1.20 & 0.17 & 1.84 & 218.00 & 66.20 & 31.80 & 11.20 \\
\hline & & Mean & 2.83 & 0.26 & 0.49 & 64.90 & 43.90 & 15.70 & 4.20 & 1.04 & 0.15 & 1.71 & 190.60 & 57.40 & 28.60 & 9.60 \\
\hline \multicolumn{17}{|l|}{ LSD at 0.05} \\
\hline B & & & 0.10 & 0.001 & 0.014 & 2.56 & 1.49 & 0.55 & 0.26 & 0.001 & 0.001 & 0.001 & 6.33 & 2.24 & 0.91 & 0.39 \\
\hline $\mathrm{A} \times \mathrm{B}$ & & & 0.08 & 0.001 & 0.001 & 2.17 & 1.26 & 0.47 & 0.22 & 0.001 & 0.001 & 0.001 & 5.35 & 1.89 & 0.76 & 0.33 \\
\hline $\mathrm{C}$ & & & 0.06 & 0.001 & 0.001 & 2.38 & 1.61 & 0.54 & 0.26 & 0.045 & 0.014 & 0.045 & 3.98 & 3.66 & 1.64 & 0.43 \\
\hline $\mathrm{A} \times \mathrm{C}$ & & & 0.05 & 0.001 & 0.001 & 2.01 & 1.36 & 0.45 & 0.22 & 0.038 & 0.001 & 0.038 & 3.37 & 3.09 & 1.38 & 0.36 \\
\hline$B \times C$ & & & 0.06 & 0.001 & 0.001 & 2.21 & 1.49 & 0.50 & 0.24 & 0.042 & 0.001 & 0.042 & 3.69 & 3.39 & 1.52 & 0.40 \\
\hline$A \times B \times C$ & & & 0.08 & 0.002 & 0.002 & 2.86 & 1.93 & 0.65 & 0.31 & 0.054 & 0.002 & 0.054 & 4.78 & 4.39 & 1.97 & 0.52 \\
\hline
\end{tabular}

IIIV. Effect of N-rates on macro and micro-nutrients concentration in grain and straw of wheat plant:

The obtained data in Table (4) showed that N, P and $\mathrm{K}$ concentrations in grain and straw exhibited progressive increases in response to the increasing $\mathrm{N}$ rates application. These results may be due to the role of nitrogen in stimulating the build of amino acids and growth hormones.

In this concern Fayiad (1989) reported that increasing $\mathrm{N}$ rates caused an increase in $\mathrm{P}$ concentration and uptake by wheat plants. Furthermore, application of (100\%) $\mathrm{N}$ from recommended dose caused significantly increase in $\mathrm{N}, \mathrm{P}$ and $\mathrm{K}$ concentration in grain and straw yields of wheat crop then (50 and 75\%) $\mathrm{N}$ from recommended dose $\mathrm{kg} \mathrm{N}$ $\mathrm{fed}^{-1}$ fertilizer These results agreement with (Anfinruda et al., 2013 and Tamado et al., 2015) who reported that there was a significant response in $\mathrm{N}, \mathrm{P}$ and $\mathrm{K} \%$ to increasing nitrogen rates.
It was observed that Table (4), a positive effect was recorded concerning application of $100 \% \mathrm{~N}$ from recommended dose, which gave the highest values in $\mathrm{N}, \mathrm{P}$ and $\mathrm{K}$ concentration by wheat plants. The relative increases of $(\mathrm{N}, \mathrm{P}$ and $\mathrm{K})$ and $(\mathrm{Fe}, \mathrm{Mn} \mathrm{Zn}$ and $\mathrm{Cu}$ ) concentration due to application rate of $(100 \%) \mathrm{N}$ from recommended dose over (50 and $75 \%$ ) $\mathrm{N}$ from recommended dose were (40.48, 30.37 and $20.71 \%)$ and $(19.65,19.35$. 15.20 and $27.59 \%)$ compared with $(50 \%) \mathrm{N}$ from recommended dose, while they were $(7.77,16.56$ and $9.84 \%)$ and $(4.45,5.53,7.69$ and $19.31 \%$ ) compared with $(75 \%) \mathrm{N}$ from recommended dose in grain of wheat plants, respectively. As well as the corresponding values of the increases in straw of wheat plant were $(16.07,29.27$ and $13.27 \%)$ and $(11.99,20.91,24.86$ and $13.73 \%)$ compared with $(50 \%)$ and $(6.17,13.82$ and $4.25 \%),(5.85,11.16,11.63$ and 5.82) compared with (75\%) $\mathrm{N}$ from recommended dose, respectively. According to 
Kutman et al. (2011) an increase in the dose of nitrogen increased the Fe content in wheat grains from (38\% to $60 \%$.

IX. Effect of $\mathbf{N}$-sources on macro and micro-nutrients concentration of grain and straw of wheat plant:

Data in Table (4) showed that the values of N, P, K, $\mathrm{Fe}, \mathrm{Mn}, \mathrm{Zn}$ and $\mathrm{Cu}$ concentration in grain and straw of wheat plant showed significantly increases affected by different sources of $\mathrm{N}$. The higher values of $\mathrm{N}, \mathrm{P}, \mathrm{K}, \mathrm{Fe}, \mathrm{Mn}$, $\mathrm{Zn}$ and $\mathrm{Cu}$ concentration in straw and grain yields were found with application of Enciabein than the other ammonium sulphate or ammonium nitrate in decreasing order. The results are in harmony with those obtained by Kumar et al. (1986). The relative increases of N, P, K, Fe, $\mathrm{Mn}, \mathrm{Zn}$ and $\mathrm{Cu}$ concentration due to application of Enciabein compared with ammonium sulphate or ammonium nitrate were $(8.40,7.22,6.71,3.23,6.00,11.79$ and11.51\%), while they were $(15.77,11.68,11.98,6.43$,
9.00, 15.50 and $24.46 \%$ ) in grain of wheat plant, respectively. The same trends were obtained for the straw yield, the relative increases were $(23.03,11.86,5.09,8.76$, $25.28,10.18$ and $21.30 \%)$ and $(27.73,21.19,10.17,11.47$, $30.56,15.88$ and $27.25 \%$ ), respectively. This may be due to an increase in utilization coefficient of Enciabein as a slow release source of nitrogen.

Generally, data showed that the highest values of $\mathrm{N}$, $\mathrm{P}, \mathrm{K}, \mathrm{Fe}, \mathrm{Mn} \mathrm{Zn}$ and $\mathrm{Cu}$ concentration in wheat plants were obtained by using Enciabein followed by ammonium sulphate and ammonium nitrate in decreasing order (Rodriguez-Otriz et al., 2006) reported that $\left(\mathrm{NH}_{4}\right)_{2} \mathrm{SO}_{4}$ fertilization can strongly affect the heavy metals accumulation in yield. The rhizosphere acidifications from nitrogen supply as well as of the plant factors (enhanced net excretion of protons or organic acid) are of particularly importance for acquisition of $\mathrm{Fe}, \mathrm{Zn}$ and $\mathrm{Mn}$ in alkaline soils.

Table 4. Effect of different nitrogen fertilizer sources and rates on macro and micro-nutrients content of grain and straw of wheat under inoculation with or without PGPR.

\begin{tabular}{|c|c|c|c|c|c|c|c|c|c|c|c|c|c|c|c|c|}
\hline \multirow{3}{*}{$\begin{array}{l}\text { PGPR* } \\
\text { (A) }\end{array}$} & \multirow{3}{*}{$\begin{array}{c}\mathbf{N} \\
\text { Source } \\
\text { (B) }\end{array}$} & \multirow{3}{*}{$\begin{array}{c}\text { The } \\
\text { percentage of } \\
\text { recommended } \\
\text { doses }(C)\end{array}$} & \multicolumn{7}{|c|}{ Wheat grain } & \multicolumn{7}{|c|}{ Wheat straw } \\
\hline & & & $\mathbf{N}$ & $\mathbf{P}$ & $\mathbf{K}$ & $\mathrm{Fe}$ & Mn & $\mathbf{Z n}$ & $\mathbf{C u}$ & $\mathbf{N}$ & $\mathbf{P}$ & $\mathbf{K}$ & $\mathrm{Fe}$ & Mn & Zn & $\mathbf{C u}$ \\
\hline & & & & $(\%)$ & & \multicolumn{4}{|c|}{$\left(\mathrm{mg} \mathrm{kg}^{-1}\right)$} & \multicolumn{4}{|c|}{$(\%)$} & \multicolumn{2}{|c|}{$\left(\mathrm{mg} \mathrm{kg}^{-1}\right)$} & \\
\hline \multirow{12}{*}{$\begin{array}{l}\text { With } \\
\text { inoculation }\end{array}$} & \multirow{4}{*}{$(\mathrm{NH} 4)_{2} \mathrm{SO}_{4}$} & $50 \%$ & 1.38 & 0.41 & 1.26 & 144.0 & 23.7 & 16.3 & 1.8 & 0.95 & 0.17 & 2.37 & 202.0 & 34.5 & 18.0 & 8.7 \\
\hline & & $75 \%$ & 1.94 & 0.48 & 1.47 & 153.0 & 27.0 & 17.9 & 2.1 & 1.08 & 0.20 & 2.65 & 214.0 & 38.2 & 22.0 & 9.1 \\
\hline & & $100 \%$ & 2.12 & 0.59 & 1.57 & 156.0 & 28.2 & 19.2 & 2.6 & 1.19 & 0.24 & 2.83 & 232.0 & 40.6 & 24.7 & 10.0 \\
\hline & & Mean & 1.81 & 0.49 & 1.43 & 151.0 & 26.3 & 17.8 & 2.2 & 1.07 & 0.20 & 2.62 & 216.0 & 37.8 & 21.6 & 9.3 \\
\hline & \multirow{8}{*}{ Enciabien } & $50 \%$ & 1.07 & 0.36 & 1.16 & 138.0 & 22.0 & 16.0 & 1.6 & 0.69 & 0.14 & 2.11 & 198.0 & 31.9 & 18.0 & 7.8 \\
\hline & & $75 \%$ & 1.76 & 0.44 & 1.25 & 147.0 & 26.7 & 17.1 & 1.7 & 0.76 & 0.17 & 2.32 & 210.0 & 34.7 & 20.3 & 8.7 \\
\hline & & $100 \%$ & 1.84 & 0.52 & 1.42 & 154.0 & 27.9 & 18.4 & 2.0 & 0.80 & 0.20 & 2.41 & 227.0 & 36.8 & 22.4 & 9.3 \\
\hline & & Mean & 1.56 & 0.44 & 1.28 & 146.3 & 25.5 & 17.2 & 1.8 & 0.75 & 0.17 & 2.28 & 211.7 & 34.5 & 20.2 & 8.6 \\
\hline & & $50 \%$ & 1.03 & 0.36 & 1.09 & 149.0 & 25.2 & 18.7 & 2.1 & 0.63 & 0.12 & 2.06 & 220.0 & 44.3 & 19.9 & 11.2 \\
\hline & & $75 \%$ & 1.66 & 0.43 & 1.22 & 156 & 28.4 & 20.2 & 2.3 & 0.72 & 0.15 & 2.24 & 239.0 & 50.2 & 23.7 & 12.0 \\
\hline & & $100 \%$ & 1.83 & 0.51 & 1.34 & 166.0 & 30.6 & 22.4 & 2.9 & 0.78 & 0.18 & 2.31 & 248.0 & 59.4 & 29.0 & 12.4 \\
\hline & & Mean & 1.51 & 0.43 & 1.22 & 157.0 & 28.1 & 20.4 & 2.4 & 0.71 & 0.15 & 2.20 & 235.7 & 51.6 & 24.2 & 11.9 \\
\hline \multirow{12}{*}{$\begin{array}{l}\text { Without } \\
\text { inoculation }\end{array}$} & \multirow{4}{*}{$(\mathrm{NH} 4)_{2} \mathrm{SO}_{4}$} & $50 \%$ & 1.22 & 0.40 & 1.14 & 140.0 & 22.0 & 15.6 & 1.6 & 0.83 & 0.16 & 2.21 & 196.0 & 28.8 & 17.4 & 8.1 \\
\hline & & $75 \%$ & 1.84 & 0.46 & 1.39 & 151.0 & 25.7 & 17 & 1.8 & 0.92 & 0.19 & 2.37 & 206.0 & 34.1 & 20.0 & 8.9 \\
\hline & & $100 \%$ & 2.09 & 0.57 & 1.52 & 154 & 26.9 & 18 & 2.4 & 0.98 & 0.22 & 2.51 & 220.0 & 38.7 & 22.3 & 9.5 \\
\hline & & Mean & 1.72 & 0.48 & 1.35 & 148.3 & 24.9 & 17.1 & 1.9 & 0.91 & 0.19 & 2.36 & 207.3 & 33.9 & 19.9 & 8.8 \\
\hline & & $50 \%$ & 1.38 & 0.41 & 1.26 & 138.0 & 21.3 & 15 & 1.6 & 0.95 & 0.17 & 2.37 & 188.0 & 30.0 & 15.9 & 7.2 \\
\hline & & $75 \%$ & 1.94 & 0.48 & 1.47 & 143.0 & 25.8 & 16.7 & 1.7 & 1.08 & 0.20 & 2.65 & 202.0 & 32.4 & 20.0 & 8.4 \\
\hline & & $100 \%$ & 2.12 & 0.59 & 1.57 & 150.0 & 27.2 & 17.9 & 1.9 & 1.19 & 0.24 & 2.83 & 218.0 & 35.0 & 21.0 & 8.9 \\
\hline & & Mean & 1.81 & 0.49 & 1.43 & 143.7 & 24.8 & 16.5 & 1.7 & 1.07 & 0.20 & 2.62 & 202.7 & 32.5 & 18.9 & 8.2 \\
\hline & & $50 \%$ & 1.07 & 0.36 & 1.16 & 143.0 & 22.9 & 17.7 & 1.8 & 0.69 & 0.14 & 2.11 & 214.0 & 38.1 & 19.3 & 10.4 \\
\hline & & $75 \%$ & 1.76 & 0.44 & 1.25 & 151.0 & 27.0 & 19.1 & 2.1 & 0.76 & 0.17 & 2.32 & 232.0 & 43.6 & 21.6 & 11.2 \\
\hline & Enciabien & $100 \%$ & 1.84 & 0.52 & 1.42 & 163.0 & 29.2 & 20.6 & 2.7 & 0.80 & 0.20 & 2.41 & 239.0 & 52.0 & 25.0 & 11.8 \\
\hline & & Mean & 1.56 & 0.44 & 1.28 & 152.3 & 26.4 & 19.1 & 2.2 & 0.75 & 0.17 & 2.28 & 228.3 & 44.6 & 21.9 & 11.1 \\
\hline & & & & & & & & & & & & & & & & \\
\hline B & & & & & & 3.6 & & & & & & 0.04 & 4.92 & 2.47 & 0.61 & 0.35 \\
\hline$A \times B$ & & & 0.001 & 0.0 & 0.054 & 3.0 & 0.9 & 0.5 & 0.14 & 0.032 & 0.0 & 0.04 & 4.16 & 2.09 & 0.55 & 0.29 \\
\hline $\mathrm{C}$ & & & 0.064 & 0.0 & 0.064 & 3.3 & 1.2 & 0.4 & 0.18 & 0.001 & 0.001 & 0.06 & 5.23 & 3.15 & 0.82 & 0.31 \\
\hline & & & 0.54 & 0.0 & 0.054 & 3.5 & 1.0 & 0.3 & 0.15 & 0.001 & 0.001 & 0.05 & 4.42 & 2.67 & 0.69 & 0.26 \\
\hline $\mathrm{B} \times \mathrm{C}$ & & & 0.059 & 0.001 & 0.059 & 3.65 & 1.1 & 0.41 & 0.17 & 0.001 & 0.001 & 0.06 & 4.85 & 2.93 & 0.76 & 0.28 \\
\hline$A \times B \times C$ & & & 0.077 & 0.002 & 0.077 & 4.72 & 1.48 & 0.53 & 0.22 & 0.002 & 0.002 & 0.08 & 6.28 & 3.79 & 0.99 & 0.37 \\
\hline
\end{tabular}

X. Effect of interaction between rates and sources of nitrogen application on macro and micro-nutrients concentration of grain and straw of wheat plants:

Data presented in Table (4) showed that the interaction between nitrogen rates and sources was significantly affected macro and micro-nutrients concentration in grain and straw of wheat plant.The addition of Enciabein at rates of (50, 75 and 100\%) $\mathrm{N}$ from recommended dose increased $(\mathrm{N}, \mathrm{P}, \mathrm{K}, \mathrm{Fe}, \mathrm{Mn}, \mathrm{Zn}$ and
$\mathrm{Cu}$ ) concentration than the addition of different sources of each $\mathrm{N}$ fertilizer rate. The average increases were (13.46, $8.64,2.5,2.74,4.99,12.36$ and $12.82 \%)$ at rate of $(50 \%) \mathrm{N}$ from recommended dose, while they were $(3.70,4.26$, $11.19,0.98,4.87,10.94$ and $11.36 \%)$ at rate of $(75 \%) \mathrm{N}$ from recommended dose, however, they were $(9.50,8.62$, $5.83,5.78,7.86,12.09$ and $10.71 \%)$ at rate of $(100 \%) \mathrm{N}$ from recommended dose for grain of wheat plant as compared with the addition of ammonium sulphate, 
respectively. Also addition of Enciabein at rates of (50, 75 and $100 \%) \mathrm{N}$ from recommended dose increased (N, P, K, $\mathrm{Fe}, \mathrm{Mn}, \mathrm{Zn}$ and $\mathrm{Cu}$ ) concentration, the average increase were $(18.46,11.11,8.75,5.48,9.98,14.84$ and $17.95 \%)$ at rate of $(50 \%) \mathrm{N}$ from recommended dose, while they were $(10.58,6.38,13.29,5.23,13.99$ and $22.73 \%)$ at rate of (75\%) $\mathrm{N}$ from recommended dose, however, they were $(12.35,10.34,11.33,7.60,7.86,15.58$ and $30.36 \%)$ at rate of $(100 \%) \mathrm{N}$ from recommended dose for grain of wheat plant as compared with the addition of ammonium nitrate, respectively.

The same trend was found in straw of wheat plant the addition of Enciabein at rates of (50,75 and 100\%) $\mathrm{N}$ from recommended dose increased (N, P, K, Fe, Mn, Zn and $\mathrm{Cu}$ ) concentration with average increases $(12.12,5.68$, $8.29,23.18,9.69$ and $22.22 \%)$ at rate of $(50 \%) \mathrm{N}$ from recommended dose, while they were $(10.26,3.19,10.83$, $22.92,7.28$ and $22.41 \%$ ) at rate of $(75 \%) \mathrm{N}$ from recommended dose, however, they were $(13.04,6.37,7.19$, $28.82,12.96$ and $19.42 \%)$ at rate of $(100 \%) \mathrm{N}$ from recommended dose as compared with the addition of ammonium sulphate fertilizer, respectively. Similarly, the average increase were $(24.24,8.95,11.06,24.88,13.52$ and $30.56 \%)$ at rate of $(50 \%) \mathrm{N}$ from recommended dose, while they were $(17.95,9.36,12.53,28.46,11.04$ and $26.29 \%)$ at rate of $(75 \%) \mathrm{N}$ from recommended dose, however, they were $(19.57,11.42,8.62,35.55,19.63$ and $24.79) \%$ at rate of $(100 \%) \mathrm{N}$ from recommended dose as compared with the addition of ammonium nitrate, respectively.

The obtained data in Table (4) showed that N, P and $\mathrm{K}$ concentrations in grain and straw were markedly increased in response to the PGPR application. The relative increases of $(\mathrm{N}, \mathrm{P}$ and $\mathrm{K})$ and $(\mathrm{Fe}, \mathrm{Mn}, \mathrm{Zn}$ and $\mathrm{Cu})$ concentration due to application of PGPR were (5.28, 3.57 and $4.08 \%)$ and $(2.20,4.88,4.75$ and $7.85 \%)$ in grain compared with un-inoculation treatment, respectively. while the increases in straw of wheat plants were $(8.26$, 6.13 and $6.76 \%)$ and $(3.77,10.23,7.83$ and $5.38 \%)$ compared with un-inoculation treatment, respectively. This increase may also explained by organic acids production from plants and bacteria in the rhizosphere, which decreased soil $\mathrm{pH}$ value and stimulate the availability of $\mathrm{P}$, $\mathrm{Ca}, \mathrm{Fe}$ and $\mathrm{Mn}$. These findings in the present study were supported by Shen et al. (2004).

XI. Effects of $\mathbf{N}$ addition on soil available concentrations of macro and micro-nutrients after harvesting of maize and wheat plants:

The residual of nitrogen in both soil of maize and wheat was significantly increased with application of nitrogen fertilizer Table (5). It was noticed that addidation (100\%) N from recommended dose significantly retained more nitrogen and was higher by (12.45and $6.11 \%$ ), in maize soil and (10.89 and 5.57\%) in wheat soil, respectively than rates of (50 and 75\%) $\mathrm{N}$ from recommended dose. The probable in significant increase in residual nitrogen could be attributed to more losses through leaching or volatilization. Although it has been reported that some species grown on acidic and alkaline soils usually prefer different forms of nitrogen (Van den Berg et al., 2005), both high $\mathrm{NO}_{3}^{-}-\mathrm{N}$ concentration and high $\mathrm{NH}^{+}{ }_{4}-\mathrm{N}$ concentration can suppress root elongation. It is worthy to notice that ammonium sulphate yielded the highest values of soil available nitrogen than ammonium nitrate and Enciabein. The relative increases in soil available $\mathrm{N}$ due to ammonium sulphate fertilization reached to (3.71 and $27.48 \%$ ) over ammonium nitrate and Enciabein in maize soil, respectively. While in wheat soil it was (5.15 and $19.97 \%)$. Considering the interaction effect, the data obtained reveal that $\mathrm{N}$ availability was affected by the interaction between nitrogen sources and nitrogen rates. It is obvious to notice that $\mathrm{N}$ availability was affected by nitrogen rates only when added as ammonium sulphate, while increasing ammonium nitrate and Enciabein rate not affected the available $\mathrm{N}$ in soil after harvesting. Marry et al. (1989) found that volatilization of ammonia was the main reason of nitrogen losses in calcareous soils. It is well established that $\mathrm{CaCO}_{3}$ is an efficient soil cementing agent that improves soil aggregation and permeability to water causing the leaching of nitrate dissolved.

The residual phosphorus and potassium in the soil was significantly decreased with increased application rate of nitrogen fertilizer Table (5). It was noticed that applied (75\% and $100 \%) \mathrm{N}$ from recommended dose significantly decreased phosphorus and potassium concentration in soil and it was lower by (18.71 and $8.99 \%)$ and (7.26 and $4.01 \%)$ in maize soil and it was lower by (39.37 and $16.41 \%)$ and (3.49 and $1.85 \%)$ in wheat soil, respectively than rate of $(50 \%) \mathrm{N}$ from recommended dose. The relative increase in soil available phosphorus and potassium due to ammonium sulphate fertilization reached to (5.24 and $17.07 \%)$ and (3.22 and 8.67) in maize soil and it was reached to (1.20 and $34.19 \%)$ and (1.09 and 5.4\%)in wheat soil, over ammonium nitrate and Enciabein, respectively. This is in agreement with the findings of Bailey (1995). Increasing nitrogen rates increased soil-Ca significantly in the three nitrogen sources. This high correspondence between nitrogen and calcium could be due to the higher microbial activity which produced $\mathrm{CO}_{2}$ and organic acids that increased the solubility of $\mathrm{CaCO}_{3}$ and hence the available $\mathrm{Ca}$. The possible explanation for decreased $\mathrm{P}$ and $\mathrm{K}$ may be due to ability of nitrogen fertilizer to mediate their utilization during plant growth (Brady, 1984).

The available concentration of $\mathrm{Fe}$ and $\mathrm{Mn}$ significantly increased with $\mathrm{N}$ addition, application of $\mathrm{N}$ with rate $(100 \%) \mathrm{N}$ from recommended dose caused relative increase in available concentration of $\mathrm{Fe}$ reaching about (6.8 and $26.8 \%$ ) for Fe and (12.6 and 27.4\%) for Mn in maize soil and about (9.0 and $19.0 \%)$ for $\mathrm{Fe}$ and (8.7 and $20.4 \%$ ) for $\mathrm{Mn}$ in wheat soil, respectively compared to (50 and $75 \%) \mathrm{N}$ from recommended dose.

The application of ammonium sulphate fertilizer caused relative increase in available concentration of $\mathrm{Fe}$ to reach about (10.42 and 12.92\%) for $\mathrm{Fe}$ and (4.86 and $9.05 \%$ ) for $\mathrm{Mn}$ in maize soil and about (8.86 and $10.80 \%$ ) for $\mathrm{Fe}$ and (3.11 and 9.78\%) for $\mathrm{Mn}$ in wheat soil, respectively. compared to ammonium nitrate and Enciabein treatment. 
Table 5.Effect of different nitrogen fertilizer sources and rates on available macro and micro-nutrients in soil after harvesting of maize and wheat plants under inoculation with or without PGPR.

\begin{tabular}{|c|c|c|c|c|c|c|c|c|c|c|c|c|c|c|c|c|}
\hline \multirow{3}{*}{$\begin{array}{l}\text { PGPR* } \\
\text { (A) }\end{array}$} & \multirow{3}{*}{$\begin{array}{c}\mathbf{N} \\
\text { Sources } \\
\text { (B) }\end{array}$} & \multirow{3}{*}{$\begin{array}{c}\text { Recommen } \\
\text { ded doses } \\
\text { of } \mathrm{N} \text { rates } \\
\text { of addition } \\
\text { (C) }\end{array}$} & \multicolumn{7}{|c|}{ Maize soil } & \multicolumn{7}{|c|}{ Wheat soil } \\
\hline & & & $\mathbf{N}$ & $\mathbf{P}$ & $\mathbf{K}$ & $\mathbf{F e}$ & Mn & Zn & $\mathbf{C u}$ & $\mathbf{N}$ & $\mathbf{P}$ & $\mathbf{K}$ & $\mathrm{Fe}$ & Mn & Zn & $\mathrm{Cu}$ \\
\hline & & & \multicolumn{7}{|c|}{$\left(\mathrm{mg} \mathrm{kg}^{-1}\right)$} & \multicolumn{7}{|c|}{$\left(\mathrm{mg} \mathrm{kg}^{-1}\right)$} \\
\hline \multirow{12}{*}{$\begin{array}{l}\text { With } \\
\text { inoculation }\end{array}$} & \multirow{4}{*}{$\left(\mathrm{NH}_{4}\right)_{2} \mathrm{SO}_{4}$} & $50 \%$ & 120.0 & 2.12 & 448.0 & 13.2 & 9.2 & 1.30 & 0.65 & 128.3 & 3.80 & 486.0 & 15.4 & 9.9 & 1.47 & 0.78 \\
\hline & & $75 \%$ & 125.0 & 1.89 & 436.0 & 16.4 & 10.0 & 1.50 & 0.72 & 133.7 & 2.98 & 470.0 & 16.7 & 10.8 & 1.58 & 0.81 \\
\hline & & $100 \%$ & 132.7 & 1.72 & 415.0 & 17.6 & 11.7 & 1.67 & 0.83 & 137.2 & 2.50 & 461.0 & 18.4 & 12.0 & 1.74 & 0.89 \\
\hline & & Mean & 125.9 & 1.91 & 433.0 & 15.7 & 10.3 & 1.49 & 0.73 & 133.1 & 3.09 & 472.3 & 16.8 & 10.9 & 1.60 & 0.83 \\
\hline & \multirow{4}{*}{$\mathrm{NH}_{4} \mathrm{NO}_{3}$} & $50 \%$ & 114.0 & 1.91 & 429.0 & 12.6 & 8.7 & 1.20 & 0.63 & 119.4 & 3.69 & 470.0 & 14.3 & 9.7 & 1.36 & 0.71 \\
\hline & & $75 \%$ & 122.0 & 1.74 & 418.0 & 14.8 & 9.8 & 1.36 & 0.70 & 126.0 & 2.94 & 468.0 & 15.9 & 10.6 & 1.52 & 0.79 \\
\hline & & $100 \%$ & 130.0 & 1.64 & 398.0 & 15.3 & 11.6 & 1.52 & 0.80 & 133.0 & 2.47 & 456.3 & 16.8 & 11.9 & 1.69 & 0.86 \\
\hline & & Mean & 122.0 & 1.76 & 415.0 & 14.2 & 10.0 & 1.36 & 0.71 & 126.1 & 3.03 & 463.1 & 15.7 & 10.7 & 1.52 & 0.79 \\
\hline & \multirow{4}{*}{ Enciabien } & $50 \%$ & 81.3 & 1.70 & 409.0 & 12.0 & 8.3 & 1.0 & 0.60 & 98.0 & 2.20 & 450.0 & 13.9 & 8.9 & 1.21 & 0.65 \\
\hline & & $75 \%$ & 93.0 & 1.64 & 396.0 & 14.3 & 9.7 & 1.26 & 0.69 & 107.0 & 2.10 & 446.0 & 14.8 & 10.0 & 1.43 & 0.75 \\
\hline & & $100 \%$ & 101.3 & 1.42 & 382.0 & 15.0 & 10.6 & 1.48 & 0.78 & 116.0 & 1.94 & 439.0 & 16.2 & 10.8 & 1.52 & 0.80 \\
\hline & & Mean & 91.9 & 1.59 & 395.7 & 13.8 & 9.5 & 1.25 & 0.69 & 107.0 & 2.08 & 445.0 & 14.9 & 9.9 & 1.39 & 0.73 \\
\hline \multirow{12}{*}{$\begin{array}{l}\text { Without } \\
\text { inoculation }\end{array}$} & \multirow{4}{*}{$\left(\mathrm{NH}_{4}\right)_{2} \mathrm{SO}_{4}$} & $50 \%$ & 115.0 & 2.0 & 439.0 & 12.6 & 8.7 & 1.20 & 0.62 & 123.0 & 3.71 & 469.0 & 14.7 & 9.4 & 1.39 & 0.70 \\
\hline & & $75 \%$ & 120.0 & 1.84 & 426.0 & 15.7 & 9.6 & 1.37 & 0.72 & 130.0 & 2.94 & 460.0 & 16.0 & 10.6 & 1.47 & 0.78 \\
\hline & & $100 \%$ & 126.0 & 1.68 & 408.0 & 16.6 & 10.5 & 1.56 & 0.81 & 134.6 & 2.41 & 452.0 & 17.9 & 11.7 & 1.70 & 0.84 \\
\hline & & Mean & 120.3 & 1.84 & 424.3 & 14.9 & 9.6 & 1.38 & 0.71 & 129.2 & 3.02 & 460.3 & 16.2 & 10.6 & 1.52 & 0.77 \\
\hline & \multirow{4}{*}{$\mathrm{NH}_{4} \mathrm{NO}_{3}$} & $50 \%$ & 109.0 & 1.90 & 416.0 & 11.7 & 7.7 & 1.10 & 0.60 & 116.7 & 3.54 & 461.0 & 13.9 & 9.4 & 1.30 & 0.66 \\
\hline & & $75 \%$ & 116.0 & 1.63 & 404.0 & 13.2 & 9.4 & 1.24 & 0.68 & 122.0 & 2.90 & 452.0 & 15.2 & 10.2 & 1.48 & 0.73 \\
\hline & & $100 \%$ & 121.0 & 1.60 & 388.0 & 14.6 & 10.0 & 1.44 & 0.78 & 130.4 & 2.40 & 447.0 & 16.5 & 11.3 & 1.60 & 0.80 \\
\hline & & Mean & 115.3 & 1.71 & 402.7 & 13.2 & 9.0 & 1.26 & 0.69 & 123.0 & 2.95 & 453.3 & 15.2 & 10.3 & 1.46 & 0.73 \\
\hline & \multirow{4}{*}{ Enciabien } & $50 \%$ & 78.6 & 1.60 & 400.0 & 11.6 & 7.6 & 0.94 & 0.60 & 94.7 & 2.00 & 443.0 & 13.2 & 8.5 & 1.20 & 0.67 \\
\hline & & $75 \%$ & 86.7 & 1.57 & 384.0 & 13.0 & 8.5 & 1.18 & 0.67 & 102.0 & 1.96 & 439.0 & 14.3 & 9.6 & 1.40 & 0.70 \\
\hline & & $100 \%$ & 94.8 & 1.40 & 378.0 & 14.3 & 9.6 & 1.36 & 0.75 & 112.0 & 1.87 & 430.0 & 16.0 & 10.3 & 1.51 & 0.78 \\
\hline & & Mean & 86.7 & 1.52 & 387.3 & 12.9 & 8.6 & 1.16 & 0.67 & 102.9 & 1.94 & 437.3 & 14.5 & 9.5 & 1.37 & 0.70 \\
\hline \multicolumn{17}{|l|}{ LSD at 0.05} \\
\hline B & & & 23.27 & 0.16 & 6.05 & 0.48 & 0.27 & 0.045 & 0.045 & 1.85 & 0.079 & 19.63 & 0.33 & 0.27 & 0.064 & 12.79 \\
\hline$A \times B$ & & & 19.66 & 0.13 & 5.11 & 0.40 & 0.23 & 0.038 & 0.038 & 1.57 & 0.066 & 16.58 & 0.28 & 0.23 & 0.054 & 10.81 \\
\hline $\mathrm{C}$ & & & 23.41 & 0.15 & 7.33 & 0.44 & 0.51 & 0.064 & 0.045 & 2.79 & 0.091 & 19.30 & 0.49 & 0.38 & 0.128 & 18.06 \\
\hline $\mathrm{A} \times \mathrm{C}$ & & & 21.36 & 0.13 & 6.19 & 0.37 & 0.43 & 0.054 & 0.038 & 2.35 & 0.077 & 16.31 & 0.41 & 0.32 & 0.108 & 15.26 \\
\hline$B \times C$ & & & 21.73 & 0.14 & 6.80 & 0.41 & 0.47 & 0.059 & 0.042 & 2.59 & 0.084 & 17.92 & 0.45 & 0.36 & 0.119 & 16.76 \\
\hline $\mathrm{A} \times \mathrm{B} \times \mathrm{C}$ & & & 28.11 & 0.18 & 8.80 & 0.53 & 0.61 & 0.077 & 0.054 & 3.35 & 0.109 & 23.18 & 0.59 & 0.46 & 0.154 & 21.69 \\
\hline
\end{tabular}

High soil available phosphorus (SAP) can reduce (Marschner, 1995). Data showed that, the relative increase Fe solubility by immobilizing Fe (Mandal and Haldar, 1980). Thus, the relationship between SAP and available $\mathrm{Fe}$ and $\mathrm{Mn}$ would be negative, which is supported by our study. When $\mathrm{N}$ addition promoted the uptake of SAP, a high level of $\mathrm{Fe}$ and $\mathrm{Mn}$ would be released, thereby increasing the available $\mathrm{Fe}$ and $\mathrm{Mn}$ in soil (Tian et al. 2016 and Wang et al. 2017).

The maximum values for available concentrations of $\mathrm{Zn}$ and $\mathrm{Cu}$ changed with the $\mathrm{N}$ addition, with (100\%) $\mathrm{N}$ from recommended dose. The minimum values of available $\mathrm{Zn}$ and $\mathrm{Cu}$ concentration appeared at rate of (50\%) $\mathrm{N}$ from recommended dose Addition of $\mathrm{N}$ at rate of (100\%) $\mathrm{N}$ from recommended dose caused relative increase in available concentration of $\mathrm{Zn}$ and $\mathrm{Cu}$ since reached (25.36 and $12.40 \%)$ and (22.11 and $12.00 \%)$ for $\mathrm{Zn}$ and $\mathrm{Cu}$ in maize soil and (18.75 and 9.02\%) and (16.10 and $8.25 \%$ ) for $\mathrm{Zn}$ and $\mathrm{Cu}$ in wheat soil, respectively compared to $(70$ and $75 \%) \mathrm{N}$ from recommended dose.

Under such conditions, ammonium sulfate could be reduce soil $\mathrm{pH}$ by their physiological reduction through its uptake resulting the release of $\mathrm{H}^{+}$ion Kirkby and Mengel (1967). Addition of ammonium nitrate decreased the $\mathrm{Zn}$ availability over the treatment of ammonium sulfate. This could be due to $\mathrm{NO}_{3}$ uptake causing alkalization of the rhizosphere by the concomitant extraction of $\mathrm{OH}^{-}$or $\mathrm{HCO}_{3}^{-}$

(Marschner, 1995). Data showed that, the relative increase
in soil available $\mathrm{Zn}$ and $\mathrm{Cu}$ due to ammonium sulphate fertilization reached to $(9.30$ and $16.05 \%)$ and $(5.29$ and $5.98 \%$ ) for $\mathrm{Zn}$ and $\mathrm{Cu}$ in maize soil; (5.13 and $11.55 \%$ ) and (5.83 and 9.37\%) for $\mathrm{Zn}$ and $\mathrm{Cu}$ in wheat soil with ammonium nitrate and Enciabein, respectively.

The residual of $\mathrm{N}, \mathrm{P}$ and $\mathrm{K}$ in the maize and wheat soils were significantly increased with addition of nitrogen fertilizer Table (5). It was noticed that inoculated seeds with PGPR significantly retained more nitrogen, phosphorus and potassium was higher by $(5.12,3.55$ and $2.36 \%)$ and $(3.02,3.61$, and $2.25 \%)$, respectively than the un-inoculation treatment, respectively. The available concentration of $\mathrm{Fe} \mathrm{Mn}, \mathrm{Zn}$ and $\mathrm{Cu}$ significantly increased with PGPR addition, application of PGPR caused relative increase in available concentration of $\mathrm{Fe}, \mathrm{Mn}, \mathrm{Zn}$ and $\mathrm{Cu}$ to reach to about $(6.02,8.93,7.32$ and $2.66 \%)$ and $(3.30$, $3.81,3.48$ and $5.40 \%$ ), respectively compared to uninoculation treatment. These results may be attributed to increasing activity and efficiency of bacteria in reduction of soil $\mathrm{pH}$ by secreting organic acids and consequently more solubility and availability of nutrients for plants. (Yadav et al., 2002). This results agreement with Wu et al. (2005) reported that using bio-fertilizers improves physically structure of soil and increases mineral materials and nitrogen for symbiosis plant. 
XII. Enzyme activities in rhizosphere of calcareous soil.

Soil enzyme activities are an indirect indication of microbial behavior which is directly correlated with soil microbial dynamics. Enzyme activities in the soil ecosystem are considered to be a major contributor of overall soil microbial activity. Data in Table (6) represents the microbial activity in the soil rhizosphere of maize and wheat plants inoculated with or without PGPR under various sources and rates of nitrogen fertilizers. Irrespective the sources or rate of nitrogen fertilizer, the microbial inoculation stimulated the overall activity or physiological activity as represented with dehydrogenase or urease, respectively.

The lowest and highest values of dehydrogenase in the rhizosphere which inoculated with PGPR were (41.86 and $63.11 \mu \mathrm{gTPF} / \mathrm{gdry}$ soil/day) for maize plant and (36.89 to $5717 \mu \mathrm{gTPF} / \mathrm{gdry}$ soil/day) for wheat plants at rate of (50\% and 100\%) $\mathrm{N}$ from recommended dose of Encibean and $\mathrm{NH}_{4} \mathrm{NO}_{3}$, respectively; while the lowest and highest values for dehydrogenase in the rhizosphere without inoculation by PGPR for maize and wheat soils respectively were (36.56 and $57.54 \mu \mathrm{gTPF} / \mathrm{g}$ dry soil/day) and (33.98 and $54.82 \mu \mathrm{gTPF} / \mathrm{g}$ dry soil/day) in the rhizosphere.at the some fertilizers source and rates. As well as the lowest and highest values of urease in the rhizosphere inoculated and without by PGPR in maize soil were (17.52 and $29.58 \mu \mathrm{g} \mathrm{NH} / \mathrm{g}$ dry soil/h) and (16.22 and $22.38 \mu \mathrm{g} \mathrm{NH}_{4} / \mathrm{g}$ dry soil/h) in maize soil, at rate of $(50 \%$ and $100 \%) \mathrm{N}$ from recommended dose of Encibean and $\mathrm{NH}_{4} \mathrm{NO}_{3}$, respectively. The lowest and highest values of urease in rhizosphere in wheat soil inoculated with PGPR and without inoculation by PGPR were (13.24 and 24.52 $\mu \mathrm{g} \mathrm{NH} / \mathrm{g}$ dry soil/h) and (10.17 and $18.72 \mu \mathrm{g} \mathrm{NH} / \mathrm{g}$ dry soil/h) also found with at the some fertilizers source and rates. The increase in dehydrogenase enzyme due to addition of bio-inoculation indicates the successful establishment and colonization on more active microorganisms in the rhizosphere of inoculated maize plants. The obtained results are in agreement with that of Araújo et al. (2014); Xun et al. (2015) who found that the soils amended with bio-fertilizers obtained more metabolically active microorganisms and, consequently, higher biological activity as well as improved the soil quality by increasing the activities of soil enzyme such as urease, sucrose, and dehydrogenase. With regard to the effect of variously mineral nitrogen fertilizers on dehydrogenase and urease responded to the sources and rates of addition fertilizers.

Table 6. Effect of different nitrogen sources and reats on soil enzyme activities in calcareous soil rhizosphere of maize and wheat plants under inoculation with or without PGPR.

\begin{tabular}{|c|c|c|c|c|c|c|}
\hline \multirow[b]{2}{*}{$\begin{array}{l}\text { PGPR* } \\
\text { (A) }\end{array}$} & \multirow[b]{2}{*}{$\begin{array}{l}\text { N Sources } \\
\text { (B) }\end{array}$} & \multirow[b]{2}{*}{$\begin{array}{l}\text { Recommended } \\
\text { doses of } N \text { rates of } \\
\text { addition }(C)\end{array}$} & \multicolumn{2}{|c|}{ Maize soil } & \multicolumn{2}{|c|}{ Wheat soil } \\
\hline & & & $\begin{array}{l}\text { Dehydrogenase, } \\
\mu g \text { TPF/gdry soil/day }\end{array}$ & $\begin{array}{c}\text { Urease } \\
(\mu \mathrm{g} \mathrm{NH} / \mathrm{g} \\
\text { dry soil/h } \\
\end{array}$ & 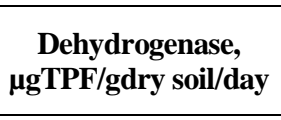 & $\begin{array}{c}\text { Urease } \\
\left(\mu \mathrm{g} \mathrm{NH}_{4} / \mathrm{g} \text { dry }\right. \\
\text { soil/h) } \\
\end{array}$ \\
\hline \multirow{12}{*}{ With inoculation } & \multirow{4}{*}{$\left(\mathrm{NH}_{4}\right)_{2} \mathrm{SO}_{4}$} & $50 \%$ & 44.15 & 22.11 & 38.73 & 16.67 \\
\hline & & $75 \%$ & 48.16 & 23.55 & 43.44 & 19.57 \\
\hline & & $100 \%$ & 54.65 & 25.36 & 48.81 & 21.16 \\
\hline & & Mean & 48.99 & 23.67 & 43.66 & 19.13 \\
\hline & \multirow{4}{*}{$\mathrm{NH}_{4} \mathrm{NO}_{3}$} & $50 \%$ & 46.88 & 26.56 & 42.19 & 20.75 \\
\hline & & $75 \%$ & 55.92 & 28.56 & 50.36 & 21.01 \\
\hline & & $100 \%$ & 63.11 & 29.58 & 57.17 & 24.52 \\
\hline & & Mean & 55.30 & 28.23 & 49.91 & 22.09 \\
\hline & \multirow{4}{*}{ Encibean } & $50 \%$ & 41.86 & 17.52 & 36.89 & 13.24 \\
\hline & & $75 \%$ & 46.71 & 17.96 & 41.94 & 14.93 \\
\hline & & $100 \%$ & 52.47 & 19.65 & 47.18 & 17.31 \\
\hline & & Mean & 47.01 & 18.38 & 42.00 & 15.16 \\
\hline \multirow{12}{*}{$\begin{array}{l}\text { Without } \\
\text { inoculation }\end{array}$} & \multirow{4}{*}{$\left(\mathrm{NH}_{4}\right)_{2} \mathrm{SO}_{4}$} & $50 \%$ & 39.58 & 16.22 & 34.89 & 10.17 \\
\hline & & $75 \%$ & 42.69 & 16.25 & 38.33 & 11.51 \\
\hline & & $100 \%$ & 49.85 & 18.36 & 44.78 & 15.24 \\
\hline & & Mean & 44.04 & 16.94 & 39.33 & 12.31 \\
\hline & \multirow{4}{*}{$\mathrm{NH}_{4} \mathrm{NO}_{3}$} & $50 \%$ & 42.26 & 21.38 & 38.37 & 14.31 \\
\hline & & $75 \%$ & 49.36 & 22.05 & 45.52 & 16.57 \\
\hline & & $100 \%$ & 57.54 & 22.38 & 51.82 & 18.72 \\
\hline & & Mean & 49.72 & 21.94 & 45.24 & 16.53 \\
\hline & \multirow{4}{*}{ Encibean } & $50 \%$ & 36.56 & 16.22 & 33.98 & 10.17 \\
\hline & & $75 \%$ & 41.59 & 16.25 & 38.32 & 11.51 \\
\hline & & $100 \%$ & 48.46 & 16.94 & 42.71 & 15.24 \\
\hline & & Mean & 42.20 & 16.47 & 38.34 & 12.31 \\
\hline \multicolumn{7}{|l|}{$\overline{\text { LSD }}$ at 0.05} \\
\hline B & & & 1.206 & 0.3484 & 0.8251 & 0.501 \\
\hline$A \times B$ & & & 1.019 & 0.2943 & 0.6972 & 0.4233 \\
\hline $\mathrm{C}$ & & & 1.215 & 0.3394 & 0.3454 & 0.4691 \\
\hline$A \times C$ & & & 1.027 & 0.2868 & 0.2918 & 0.3964 \\
\hline $\mathrm{B} \times \mathrm{C}$ & & & 1.128 & 0.3151 & 0.3206 & 0.4355 \\
\hline $\mathrm{A} \times \mathrm{B} \times \mathrm{C}$ & & & 1.461 & 0.4077 & 0.4149 & 0.5635 \\
\hline
\end{tabular}


The addition of ammonium nitrate fertilizers maximizes the dehydrogenase activity by 11.25 or $7.46 \%$ over ammonium sulphate or Encibean, respectively in the soil of maize yield. While in the soil of wheat addition of Encibean was superior compared with the other two sources of fertilizer.The percentages of relative increases were 11.70 and $8.78 \%$ for the dehydrogenase activity with addition of ammonium sulfate compared with ammonium nitrate and Enciabein respectively. On the other hand, maximize urease were 27.94 or $16.01 \%$ in maize soil; while in the soil of wheat recorded percentages of relative increases were 24.73 and $13.84 \%$ for the urease activity with addition of ammonium sulfate compared with ammonium nitrate and Enciabein fertilizers in the soils of maize and wheat, respectively.

The relative increase of dehydrogenase $\mu \mathrm{gTPF} / \mathrm{gdry}$ soil/day and urease ( $\mu \mathrm{g} \mathrm{NH} / \mathrm{g}$ dry soil/h) in the rhizosphere which inoculated with PGPR were (10.14 and 21.25) for maize soil and (9.34 and 27.03) for wheat soil respectively. Furthermore, a gradual increase in dehydrogenase due to an increase of any fertilizers rate against slight variation in urease activity. The data recorded that, increases in the dehydrogenase enzyme may be attributed to improvement in shoot or root growth which in turn was reflected microbial activity as a result to root exudates in the rhizosphere of fertilized plants. This was beside the mineral fertilizer which could be utilized as a nutrient source for the microorganisms in the rhizosphere to stimulate the microorganisms to metabolize the organic matter which appeared as increases in the dehydrogenase enzyme. The obtained date was in agreement with ElTahlawy (2018) who stated that the dehydrogenase enzymes activity significantly increased in a progressive manner as the mineral nitrogen fertilizer increased under the treatments of microbial additives or compost tea.

\section{REFERENCES}

AOAC (1990). Official methods of analysis of the Association of Official Analytical Chemists,. 15 Ed., Washington, D.C.

Abd El-Hameed, A.H. (2002). Plant growth and uptake of $\mathrm{N}, \mathrm{Fe}, \mathrm{Mn}$ and $\mathrm{Zn}$ in response to $\mathrm{N}$-fertilizers (soluble and slow release) under conditions of chelated and mineral (sulphate) forms of applied Fe. Mn or Zn. Annals of Agric. Sci., Moshtohor., 40(3): 1949-1962.

Ahmed, A.G.; Hassanein, M.S.; Ahmed, M.A. and Nabila, M. Zaki, (2009). Response of two wheat cultivars grown in newly cultivated lands to potassium and slow release $\mathrm{N}$ fertilizers. Modern J. of Applied Biological Sci., Crop Science, 3(2): 51-61.

Amanullah, K. (2016). Rate and timing of nitrogen application influence partial factor productivity and agronomic NUE of maize (Zea mays L) planted at low and high densities on calcareous soil in northwest Pakistan. J.Plant Nutr. 39: 683-690.

Amanullah, K.; S.Hassan and S. Malhi (2011). Phenology and seed quality response of rape (B. napus) versus mustard (B. juncea) to sulfur and potassium fertilization in northwest Pakistan. J. Plant Nutr. 34: 1175-1185.
Amanullah, S.S.; Shah, Z.; Khalail, S.K.; Jan, V and Jan, M.T. (2014). Effects of variable nitrogen source and rate on leaf area index and total dry matter accumulation in maize (Zea mays L.) genotypes under calcareous soils. Turk. J. Field Crops. 19: 276-284.

Anfinruda, R. ; Cihacekb, L.; B.L.Johnsona, B.L.; Jic, Y. and Bertia, M.T. (2013). Sorghum and kenaf biomass yield and quality response to nitrogen fertilization in the Northern Great Plains of the USA. Industrial Crops and Products, 50:159-165.

Araújo, A.S.F.; J. R. Oliveira; R.M. Araújo, and Gomes, R.L.F. (2014). Biofertilizers on soil microbial biomass and activity, Revista Brasileira de Ciências Agrárias - Brazilian Journal of Agricultural Sciences, 9: 545-49.

Bailey, J.S. (1995). Liming and nitrogen efficiency: some effects of increased calcium supply and increased soil $\mathrm{pH}$ on nitrogen recovery by perennial ryegrass. Communications in Soil Sci. and Plant Analysis. 26: $1233-1246$.

Benton, J. and Jones, Jr. (2001). Laboratory guide for conducting soil tests and plant analysis.

Brady, C. (1984). The nature and properties of soils. Macmillan Publishing Company, New York. USA.

Casida, L. (1977). Microbial metabolic activity in soil as measured by345dehydrogenase determinations. Appl. Environ Microbiol.34 6: 630-636.

Cavender, N.D.; Atiyeh, R.M. and Knee, M. (2003). Vermicompost Stimulates mycorrhizal colonization of roots of Sorghum bicolor at the expense of plant growth. Pedobiologia, 47: 85-89.

Darwish, D.S. (1998). Wheat production as affected by ammonia gas injection in the soil and application of $\mathrm{Zn}$ and their interaction. Agric. Sci. Mansura Univ., 22(2): 899-905.

Diez, J.A.; R. Roman; C. Cartagena; A. Vallejo; R. Bustos and H. Caballero (1994). Controlling nitrate pollution of aquifers by using different controlled release fertilizers in maize crop. Agr. Ecos. Envi., 48: 49-56.

El-Aila, H.I.; M. Abou Seeda and M. Ziada (2001). New approach for controlling the release of nitrogenous fertilizers and their effects on sorghum plants. Egypt. J. Appl. Sci., 76(6): 324-346.

El-Kramany, M.F. (2001). Effect of organic mature and slow-release $\mathrm{N}$-fertilizers on the productivity of wheat (Triticum aestivum L.) in sandy soil. Acta Agron. Hungarica, 49:379-385.

El-Tahlawy, Y. A. ( 2018). Effect of microbial additives and compost tea on growth and productivity of wheat plants fertilized by mineral nitrogen in sandy soil. Menoufia J. Soil Sci., 3: 301 - 16.

EPA. (1991). Methods for the Determination of Metals in Environmental Samples. Office of research and development Washington DC 20460 pp. 23 - 29 and $83-122$.

Fayiad, M.N. (1989). Effect of N, P and Zn on growth and nutrients contents of wheat plants grown in sandy soils. Egypt. J. Soil Sci., Special Issue: 413-423. 
Gupta, V.K. and Polalia B.S. (1991). Influence on N carriers and $\mathrm{Zn}$ levels on $\mathrm{Cu}, \mathrm{Mn}$ and $\mathrm{Fe}$ nutrition on maize (Zea mays L.). Indian J. of Agri. Rese., 25(1): 1-6.

Hanan,Taha, N.(2008). Response of rice plant to some different fertilizer compounds.Msc. Thesis, Fac.of Agric.Kafr El Shiekh Univ. Egypt.

ICARDA "International Center for Agricultural Research in the Dry Areas" (2013). Methods of soil, Plant, and water analysis: A manual for the West Asia and North Africa region. Estefan, G., Sommer, R. and Ryan, J. $3^{\text {th }}$ edition. Box 114/5055, Beirut, Lebanon.

Kirkby, E.A. and Mengel, K. (1967). Ionic balance in different tissues of the tomato plant in relation to nitrate, urea or ammonium nutrition. Plant Physiol., 42: 6-14.

Kolhe, S. S. and. Mittra, B.N (1989). Evaluation of slowrelease nitrogen fertilizers in rice-wheat cropping system. Indian J. of Agronomy, 34, 137-138.

Kumar, V.V.S.; Ahlawat A.R.S. and Yadav, D.S. (1986). Interactions of nitrogen and $\mathrm{Zn}$ in pearl millet: 2 Effect on concentration and uptake of phosphorus, potassium, iron, manganese and copper. Soil Sci., 142: 340-345.

Kutman, U. B.;Yildiz, B. and Cakmak, I. (2011). Effect of nitrogen on uptake, remobilization, and partitioning of zinc and iron throughout the development of durum wheat. Plant Soil, 342 (1); 149-164.

Lawrence, J.R; Ketterings, Q.M. and Cherney, v (2008). Effect of nitrogen application on yield and quality of corn. Agron J.; 100(1): 73-9.

Mandal, L. N. and Haldar, M. (1980). Influence of phosphorus and zinc application on the availability of zinc, copper, iron, manganese, and phosphorus in waterlogged rice soils. Soil Sci., 130, 251-257.

Marry, B.; Recous, S. and Machet, I.M. (1989). A comprehensive approach to the fertilizer part of plant. Symposium Proceedings, Edenburg. 6-18 Sept., U.K.

Marschner, H. (1995). Mineral nutrition of higher plants. Academic press Limited, London, pp: 889.

Maynard, D.N. and Lorenz, O.A. (1979). Controlled release fertilizers for horticultural crops. Hort. Rev. 1: 79140.

McGarity-, J. W. and Myers, M.G. (1967). A survey of urease activity in soils of northern New South Wale Plant and Soil, 27:217-238.

Mengel, K. and Kirkby, E.A. (1982). Principles of plant Nutrition. Publisher, International Potash Institute, 335-368.

Meshram, S.U. and Shende, S.T. (1993). Total nitrogen K uptake by maize with Azotobacter inoculation. Plant and Soil, 69: 275-280.

Metwally, T.F.; Gewaily, E.E. and Naeem, E.S. (2011). Nitrogen response curve and nitrogen use efficiency of Egyptian Hybrid Rice. J. Agric. Res. Kafer ElSheikh Univ., 37(1): 73-84.

Murillo, J.M.; Moreno, F.; Cabrera, F. and Castro, C. (1992). Corn response to two fertilization rates under SW Spain conditions. Communications in Soil Science and Plant Analysis, 23(15 and 16): 167-177.
Namvar, A. and Khandan, T. (2015). Inoculation of rape seed under different rates of inorganic nitrogen and sulfur fertilizer: impact on water relations, cell membrane stability, chlorophyll content and yield. Arch Agron Soil Sci., 61(8): 1137-49.

Purseglove, J.W. (1972). Tropical crop. Monocotyledons. Longmans, London, pp. 300-333.

Rodriguez-Ortiz, J.C.; Valdez-Vepeda, R.D.; Lara-Mireles, J.L.; Rodriguez-Fuentes, H.; Vazquez-Alvarado, R.E.; Magallanes-Quintanar, R. and GarciaHernandez, J.L. (2006). Soil Nitrogen Effects on Phytoextraction of Cadmium and Lead by Tabacco (Nicotiana tabacum L.). Bioremediation J., 10(3): 105-114.

Sampath,O; Madhavi, M. and Rao, P.C. (2013). Evaluation of genotypes and nitrogen levels for yield maximization in rabi maize (Zea mays L.). Int. J. Innov. Res. Dev., 2:314-318.

Sarhan, S.H.; Mohamed, M.R.; Abd El-Salam, H.Z. and Bader, M.M.A. (2004). Influence of nitrogen sources on growth, yield, some macro and micronutrients content of maize plant (Zea mays, L.) in salt affected soils. J. Agric. Sci. Mansoura Univ., (3): 1589-1601.

Shen, J.; Li, R.; Zhang, F.; Fan, J.; Tang, C. and Rengel, Z.. (2004). Crop yields, soil fertility and phosphorus fractions in response to long-term fertilization under rice monoculture system on a calcareous soil. Field Crop Res. 86: 225-238.

Snedecor, G.W. and Cochran, W.G. (1980). Statistical Methods.Iowa State Univ. Press, 7.

Soltanpour, P.N. and Schwab, A. P. (1991). Determination of nutrient availability element toxicity by $\mathrm{AB}$ DTPA. Soil Test and ICPS Adv. Soil Sci., 16: $165-$ 190.

Tamado, T.; Dawit, D. and Sharma, J. J. (2015). Effect of Weed Management Methods and Nitrogen Fertilizer Rates on Grain Yield and Nitrogen Use Efficiency of Bread Wheat (Triticum aestivum L.) in Southern Ethiopia. East African. Journal of Sciences, 9(1): 15-30.

Tian, Q.; Liu. N.; Bai, W.; Li, L.; Chen, J.and Reich, P. B. (2016). A novel soil manganese mechanism drives plant species loss with increased nitrogen deposition in a temperate steppe. Ecology 97, 6574.

Van den Berg, L.J.L.; Dorland, E.; Vergeer, P.; Hart, M. A.; Bobbink, R. and Roelofs, J. G. ( 2005). Decline of acid-sensitive plant species in heathland can be attributed to ammonium toxicity in combination with low pH, New Phytol., 166: 551564.

Wang, R.; Dungait, J. A. J.;.Buss, H. L; Yang, S.; Zhanga, $\mathrm{Y}$. and $\mathrm{Xu}, \mathrm{Z}$. (2017). Base cations and micronutrients in soil aggregates as affected by enhanced nitrogen and water inputs in a semi-arid steppe grassland. Sci. Total Environ. 575: 564-572.

Wenming D.; Zhijun, G.; Jinzhou, D.; Liying, Z. and Zuyi, T. (2001). Sorption characteristics of $\mathrm{Zn}$ (II) by calcareous soil-radiotracer study. Appl. Radiat. Isotop., 54: 371-375. 
Wu, S.C.; Caob, Z.H.; Lib, Z.G.; Cheunga, K.C. and Wong, M.H. (2005). Effects of bio-fertilizer containing $\mathrm{N}$-fixer, $\mathrm{P}$ and $\mathrm{K}$ solubilizers and $\mathrm{AM}$ fungi on maize growth: a greenhouse trial. Geoderma. 125: 155-166.

Xun, F.; Xie, B.; Liu, S. and Guo, C..(2015). Effect of plant growth-promoting bacteria (PGPR) and arbuscular mycorrhizal fungi (AMF) inoculation on oats in saline-alkali soil contaminated by petroleum to enhance phytoremediation. Environ. Sci. Pollut. Res. Int., 22: 598-608.
Yadav, R.D.; Keshwa, G.L. and Yadva, S.S (2002). Effect of integrated use of FYM, urea and sulphur on growth and yield of Isabgol (Plantago ovata). J Medicinal and Aromatic Plant Sci.; 25: 668-671.

Zeidan, M.S; Amany, A. and El-Kramany, M.F.(2006). Effect of N-fertilizer and plant density on yield and quality of maize in sandy soil. Res J Agric Biol Sci.; 2(4): 156-61.

Zhang, C. L.; Zhu, X. M. and Hu, S. N. (1998). Studies of the effect of slow-release urea and nitrogen use efficiency. Soils and Fertilizers, Beijing, 6: 11-13.

\section{تأثثير المحفزات الحيوية و مصادر مختلفة من النيتروجين على إنتاجية محاصيل الذرة والقدمح بالاراضي الجيرية

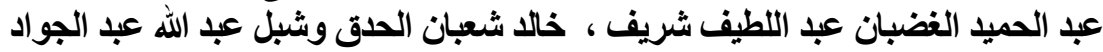

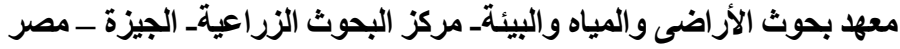

يعد الحفاظ على خصوبة التربة وإستخدام المغذيات النباتية بكميات كافية ومتوازنة أحد العوامل الرئيسية فى زيادة إنتاجية المحاصيل

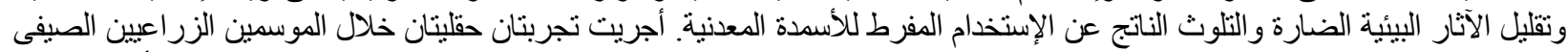

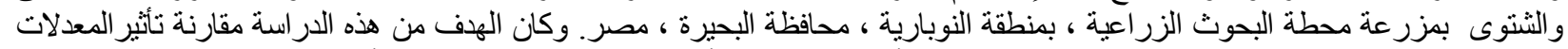

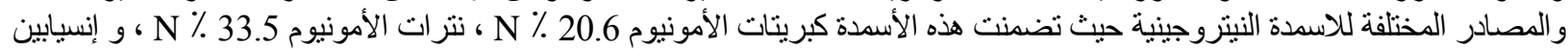

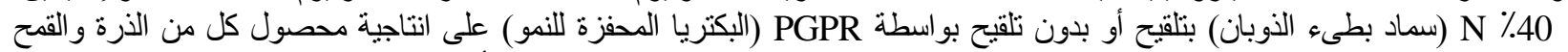

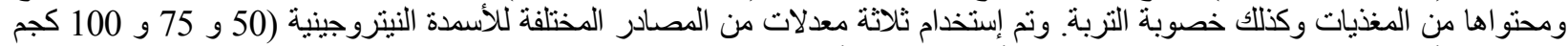

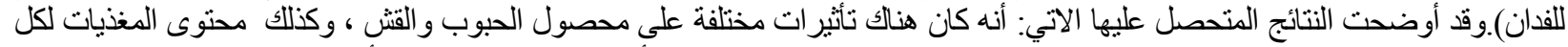

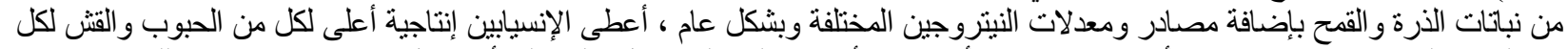

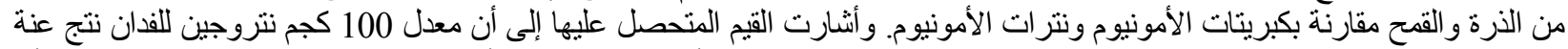

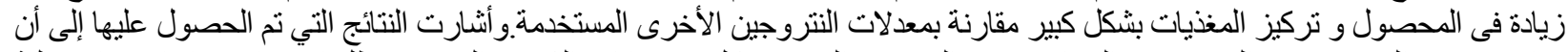

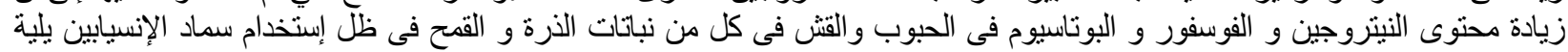

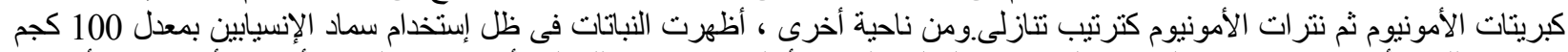

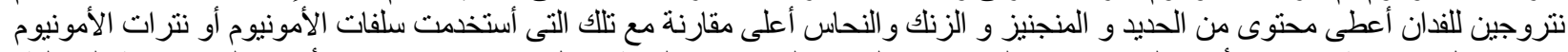

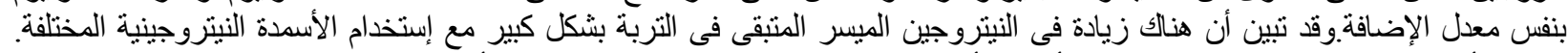

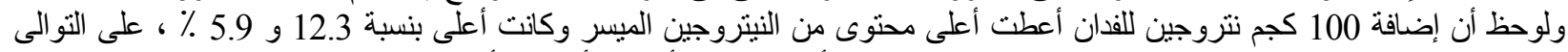

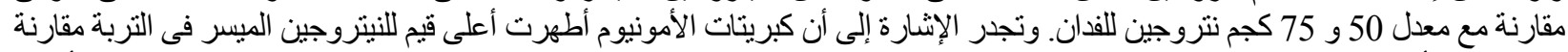

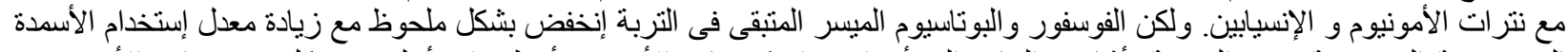

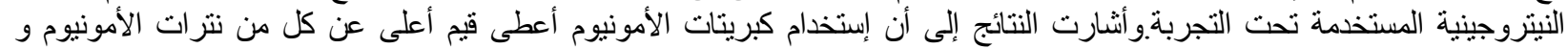

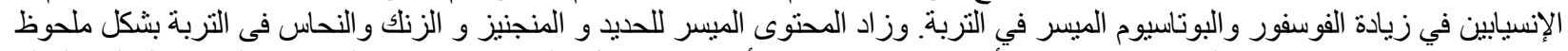

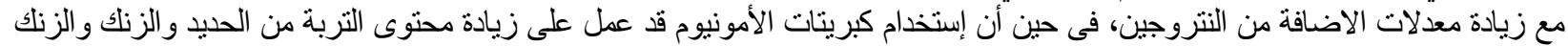

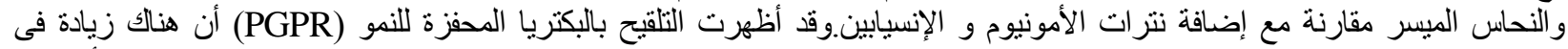

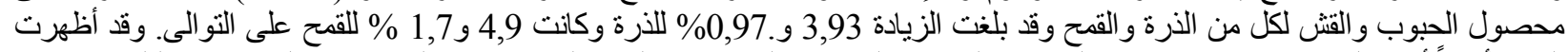

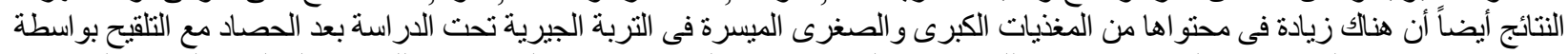

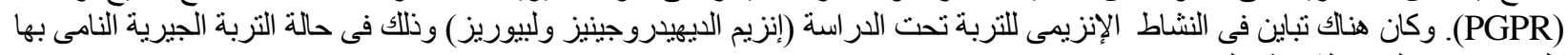
كل من نباتات الذرة الثنامية والقمح. 